\title{
04/RT/15
}

Páipéar Taighde Teicniúil

Research Technical Paper

\section{Location Decisions of Non-Bank Financial Foreign Direct Investment: Firm-Level Evidence from Europe}

Ronald B. Davies and Neill Killeen 


\section{Non-Technical Summary}

The financial crisis highlighted the globalisation of the financial sector including the substantial growth and complexity of corporate structures in the non-bank financial sector. Over the last decade, the non-bank financial sector in the euro area has more than doubled in size reflecting the substantial growth in "shadow banking" activities. Despite the increasing importance and internationalisation of non-bank financial institutions, a large proportion of the non-bank financial sector remains unmapped as granular balance sheet information is not available for almost half of the sector. Motivated by these data gaps and employing firm-level data, this paper examines the location decisions of 8,724 newly incorporated foreign affiliates in this sector across 27 European countries over the period 2004 to 2012.

This paper contributes by analysing several issues. First, we examine at a basic level the location of the financial activities of MNEs in the non-bank financial sector in Europe, finding substantial concentration. Second, we estimate the effect of key factors determining the location decisions of non-bank financial FDI using a conditional logit estimator. Drawing on the existing theoretical and empirical literature we include a number of host country characteristics which are likely to effect expected profits from locating in a particular country. Gravity variables describe market size and market access and have been used extensively in the empirical FDI literature. In addition, we account for a range of cultural, geographical and institutional characteristics of the host country which may influence the location decisions of firms. Third, we compare so called "brass plate" entities (which despite large assets may have few employees) to other firms. Finally, we conduct a series of robustness checks using different subsamples of firms to account for heterogeneity of determinants across different home countries of FDI, finding consistency across groups.

Our results suggest that many traditional determinants of overall FDI, including market size, barriers between the home and host, taxes, and regulation have comparable effects in this sector. The first two of these results may be somewhat surprising given the perception that this industry is very footloose and not tied to a specific geographic location. That said, our results do mirror what is found in the banking FDI literature. In addition, we find that the determinants of brass plate investment is comparable to that of larger firms alleviating concerns over differential responses between these two groups. Thus, our estimates suggest that non-bank financial FDI behaves much like FDI in the banking sector and overall FDI. On the whole, while we do find an important effect from taxes, our analysis also highlights the importance of traditional gravity variables such as the home and host country sharing a common language and common legal system in determining non-bank financial FDI. 


\title{
Location Decisions of Non-Bank Financial Foreign Direct Investment: Firm-Level Evidence from Europe*
}

\author{
Ronald B. Davies ${ }^{\dagger} \quad$ Neill Killeen ${ }^{\ddagger}$
}

October 2015

\begin{abstract}
The non-bank financial sector in the euro area has more than doubled in size over the last decade reflecting the substantial growth in shadow banking activities. However, a large proportion of the non-bank financial sector remains unmapped as granular balance sheet information is not available for almost half of the sector. Motivated by these data gaps and employing firm-level data, this paper examines the location decisions of newly incorporated foreign affiliates in the non-bank financial sector across 27 European countries over the period 2004 to 2012. The probability of a country being chosen as the location for a new foreign affiliate is found to be negatively associated with higher corporate tax rates and geographic distance but increases with the size and financial development of the host country. The financial regulatory regime in the host country and gravity related controls such as the home and host country sharing a common legal system, language, border and currency are also found to impact the likelihood of non-bank financial FDI.
\end{abstract}

\section{JEL classification: F23, F65, G23, G32.}

Keywords: Foreign direct investment, financial sector, shadow banking, location decisions, conditional logit models.

*The views expressed in this paper are those of the authors and do not necessarily reflect those of the Central Bank of Ireland, the ESCB or the ESRB. The authors would like to thank Daragh Clancy, Stefanie Haller, Hendrik Jungmann, Fergal McCann, Kitty Moloney, Gerard O’Reilly, Iulia Siedschlag, conference participants at the 2015 Annual Congress of the International Institute of Public Finance, 2015 European Trade Study Group Conference, 2015 Irish Economic Association Conference, and seminar participants at the Central Bank of Ireland for helpful comments on earlier drafts of this paper. Any remaining errors are our own.

†University College Dublin; ronbdavies@gmail.com

$\ddagger$ Central Bank of Ireland and University College Dublin. Currently on secondment to the ESRB Secretariat; neill.killeen@esrb.europa.eu 


\section{Introduction}

The financial crisis highlighted the globalisation of the financial sector including the substantial growth and complexity of corporate structures in the non-bank financial sector (sometimes referred to as the "shadow banking" sector). A key feature of the globalisation of the financial sector was the activities of multinational enterprises (MNEs). A recent strand of the foreign direct investment (FDI) literature has focused on the effects of FDI in the financial sector (Goldberg, 2007), with empirical evidence suggesting that financial FDI may be less beneficial to the host country than general or greenfield FDI (Ostry et al., 2010).

The financial sector comprises several types of entities, including banks and insurance companies. Of increasing importance, however, is the size and activities of non-bank financial institutions. In particular, a large number of these institutions are currently unmapped, as reflected by the large residual of approximately 48 per cent in the other financial intermediaries (OFI) sector in the euro area (see Figure 1). The increasing importance and internationalisation of non-bank financial institutions coupled with this data gap raises a number of important questions which are relevant to both researchers and policymakers alike. Indeed, policy initiatives at a European level, including the European Commission's 'Capital Markets Union' (CMU) ${ }^{1}$ proposal has focused specifically on the non-bank financial sector. However, policy initiatives such as the CMU require understanding the activities of non-bank financial institutions, including the determinants for cross-border investment. Despite this need, there is little research on the non-bank financial sector and particularly on FDI in this sector. ${ }^{2}$

This paper contributes by examining the determinants of location decisions of new non-bank financial foreign affiliates. ${ }^{3}$ Few studies in the empirical literature on firm

\footnotetext{
${ }^{1}$ See European Commission (2015) for an overview of the CMU proposal. The objective of the CMU is to maximise the benefits of the capital markets and non-bank financial institutions as funding channels for the real economy.

${ }^{2}$ See OECD (2014) for an analysis of the impact of non-bank financial institutions on FDI flows and stocks.

${ }^{3}$ Banks and insurance companies' accounts are not available on the Amadeus database. Therefore, the majority of our sample consists of firms which would be classified within the OFI sector. Our sample includes multi-affiliate firms within the same corporate group. However, without consolidated information on these firms, these foreign affiliates cannot be identified or tracked.
} 
location choice have examined sector-specific FDI in Europe while most exclude the financial sector from their analysis. ${ }^{4}$ Moreover, many of the papers which examine financial FDI focus on the activities of foreign banks (Grosse and Goldberg, 1991; Yamori, 1998; Buch and Lipponer, 2007; Claessens and van Horen, 2014a; Huizinga, Voget and Wagner, 2014; Merz, Overesch and Wamser, 2015). To the best of our knowledge no study examines the determinants of location decisions for FDI in the non-bank financial sector. This paper aims to fill this important gap.

In particular, we analyse several issues. First, we examine at a basic level the location of the financial activities of MNEs in the non-bank financial sector in Europe, finding substantial concentration. Second, we estimate the effect of key factors determining the location decisions of non-bank financial FDI using a conditional logit estimator. Third, we compare so called "brass plate" entities (which despite large assets may have few employees) to other firms. We do this to examine how, in light of Goldberg (2007), non-bank financial FDI behaves differently to overall FDI. To do all of this, we construct a unique firm-level dataset of 8,724 newly incorporated foreign affiliates in the non-bank financial sector in the European Union (EU) over the 2004-2012 period.

Our results suggest that many traditional determinants of overall FDI, including market size, barriers between the home and host, taxes, and regulation have comparable effects in this sector. The first two of these results may be somewhat surprising given the perception that this industry is very footloose and not tied to a specific geographic location. That said, our results do mirror what is found in banking FDI. For example, the negative coefficient we obtain for distance is consistent with the findings of Buch (2005) and Claessens and van Horen (2014a). In addition, we find that the determinants of brass plate investment is comparable to that of larger firms alleviating concerns over differential responses between these two groups. Thus, our estimates suggest that non-bank financial FDI behaves much like FDI in the banking sector and overall FDI. In addition, although we do find an important effect from taxes, the sig-

\footnotetext{
${ }^{4}$ An exception is Lawless et al. (2015) who include financial services firms in their sample of firms.
} 
nificance of other determinants of FDI works to reduce concerns that FDI in this sector will merely flow to the lowest tax locations or those with less intrusive regulation.

The rest of the paper is structured as follows. Section 2 provides a brief overview of the non-bank financial sector. Section 3 situates our work within the existing literature. The data used is described in Section 4. Section 5 discusses the empirical methodology and our control variables. Section 6 contains the results while Section 7 concludes.

\section{The Non-Bank Financial Sector}

According to the ECB (2014), the size of the non-bank financial sector in the euro area has grown significantly in recent years, with assets increasing from $€ 9$ trillion in 2003 to $€ 19$ trillion in $2013 .^{5}$ This in part reflects the growth of shadow banking activity in the euro area as financial institutions adjust their activities and corporate structures in light of the increased regulatory requirements of the banking sector. Shadow banking can be broadly defined as credit intermediation outside the traditional banking system and therefore it is a catch-all term for a host of non-bank financial institutions engaged in bank-like activities. For example, in response to increased regulatory scrutiny, banks may be motivated to move some of their activities off balance sheet and establish separate entities to perform specific financial activities. In addition, large MNEs and other non-financial corporations (NFCs) may decide to establish new entities to engage in activities on behalf of the group parent or to take advantage of tax regimes in particular countries. However, in line with the current Financial Stability Board (FSB) definition ${ }^{6}$, it is only non-bank financial institutions who are engaged in credit intermediation that are considered shadow banking entities.

At present, a large portion of the non-bank financial sector in the euro area remains

\footnotetext{
${ }^{5}$ These data refer to total assets of money market funds (MMFs) and other financial intermediaries (which include all non-monetary financial institutions apart from insurance firms and pension funds) resident in the euro area. Assets of the banking sector (which includes financial assets of monetary financial institutions (MFIs) excluding money market funds (MMFs) and the Eurosystem) rose from $€ 19$ trillion to $€ 30$ trillion over the same period.

${ }^{6}$ The FSB define shadow banking as "credit intermediation involving entities and activities outside the regular banking system" or non-bank credit intermediation in short (FSB, 2013).
} 
unmapped with around 48 per cent attributed to an unspecified sector (see Figure 1). ${ }^{7}$ Therefore, understanding the activities and the location decisions of non-bank financial FDI has important policy implications. For example, many of the newly incorporated foreign affiliates in our sample would fall within this large residual and are counted within the OFI classification of flow of funds data. OFIs are a diverse range of entities which are subject to lighter regulatory requirements than monetary financial institutions (MFIs). ${ }^{8}$ The OFI sector includes financial corporations engaged in lending such as financial leasing (including aircraft leasing) or finance companies, specialised financial corporations such as factoring firms, special purpose vehicles (SPVs) including financial vehicle corporations (FVCs) engaged in securitisation activity, financial holding companies, investment funds and securities and derivatives dealers. ${ }^{9}$

Despite the fact that some OFI entities are engaged in credit intermediation, a large proportion of these institutions remain outside of the regulatory perimeter in many EU Member States. Appendix 1 contains a glossary with definitions of these financial institutions and activities. While there are many different types of institutions, some OFIs such as SPVs may be established as brass plate companies meaning they have no physical presence in the host country and therefore create little or no economic activity or employment. Entities such as FVCs, SPVs and other conduits classified within the OFI sector can also inflate and distort traditional macro-financial data such as balance of payments and external debt statistics. ${ }^{10}$ As non-bank financial institutions are subject to lighter regulatory requirements than banks, they can potentially be used as part of regulatory arbitrage strategies which can exacerbate vulnerabilities within the financial system.

\footnotetext{
${ }^{7}$ For a discussion on shadow banking data gaps at a global level, see IMF (2014).

${ }^{8} \mathrm{~A}$ number of existing and forthcoming securities and markets regulations capture some activities of OFI entities if these entities engage in particular activities. For example, entities engaged in over-thecounter (OTC) derivative transactions will be captured by the European Market Infrastructure Regulation (EMIR) and must report information on these transactions to trade repositories. However, unlike most MFIs, OFIs are not micro-prudentially supervised by financial authorities.

${ }^{9}$ Under ESA 2010, financial holding companies have been reclassified as captive financial institutions and money lenders.

${ }^{10}$ Creedon, Fitzpatrick and Gaffney (2012) document the large impact OFIs resident in Ireland have on Irish external debt statistics. Similarly, Claassen and van den Dool (2013) describe the effects of including SPEs on balance of payments and FDI statistics by taking the Netherlands as a case study.
} 
Depending on the nature of their activities ${ }^{11}$ and the definition of shadow banking ${ }^{12}$ applied, some of the entities in our sample may also be classified within the European shadow banking system. ${ }^{13}$ These entities' activities pose challenges for compilers of macroeconomic statistics while their activities also present new challenges for financial authorities concerned with monitoring the scale and nature of shadow banking activities across Europe. ${ }^{14}$

\section{Related Literature}

Firms face a number of decisions when setting up their international activities and associated corporate structures. First, there is the choice of whether to serve foreign markets through the provision of cross-border services or a foreign affiliate. Second, if the firm chooses FDI, there is the question of where to locate. There is a large and growing number of studies which examines these FDI location decisions. One strand of the literature focuses on the wider determinants of location decisions (Head and Mayer, 2004; Basile et al., 2008). Using both conditional logit and nested logit models, Head and Mayer (2004) focus on the determinants of location choice by Japanese firms in Europe. Basile et al. (2008) analyse the determinants of location choice of MNEs in Europe. They estimate a mixed logit model on a sample of foreign firms located in 50 European regions over the period 1991-1999. They find that agglomeration economies (proxied by the number of domestic and foreign firms in each region) and the ability of regions to attract EU structural funds are important determinants in location decisions.

A second strand of the literature examines the impact of taxation on FDI location decisions (Devereux and Griffith, 1998b; Hebous et al. 2011; Barrios et al. 2012; Law-

\footnotetext{
${ }^{11} \mathrm{~A}$ number of firms in our sample are engaged in activities which would not be classified as shadow banking activities. For example, according to Broos et al. (2012), the majority of the OFI sector in the Netherlands are not engaged in financial intermediation.

${ }^{12}$ The FSB define shadow banking as "credit intermediation involving entities and activities outside the regular banking system" or non-bank credit intermediation in short (FSB, 2013). However, there are a number of alternative definitions of shadow banking applied in the academic literature. For example, Claessens and Ratnovski (2014) define shadow banking as "all financial activities, except traditional banking, which require a private or public backstop to operate."

${ }^{13}$ Bakk-Simon et al. (2012) discuss the components of the euro area shadow banking system.

${ }^{14}$ Constâncio (2015) describes the statistical challenges of measuring shadow banking in the euro area.
} 
less et al. 2015). Devereux and Griffith (1998b) examine the impact of taxation on the location decisions of foreign firms in Europe. Conditional on a firm having decided to establish in Europe, they find that a one per cent increase in the effective average tax rate in the UK would lead to a reduction in the probability of a foreign firm locating there by around 1.3 per cent. Likewise, Barrios et al. (2012) find that both host and home country taxation have a negative impact on the location of new foreign subsidiaries. Using data on MNEs operating in 33 European countries over the period 1999-2003, they find that home country corporate taxation of foreign source income has an independent, strongly negative effect on the probability of location decisions in potential host countries. Lawless et al. (2015) also examine the impact of corporate taxation on MNEs' location decisions. They use data on new MNEs located across 26 European countries from 2005 to 2012 and find a consistent negative effect of the corporate tax rate on the probability of a country being chosen as a location. They use a number of alternative measures of corporate taxation while their analysis suggests that financial sector firms are the most sensitive to changes in corporate tax rates.

A less developed third strand of the literature draws on more granular regional data to examine the determinants of sector-specific FDI locations decisions (Siedschlag et al. 2013a; 2013b). Our paper is related to all three strands of literature given that we focus on sector-specific FDI determinants, including corporate taxation. Regarding studies of financial sector FDI more generally, there are a number of papers which explore the activities of foreign banks (Grosse and Goldberg, 1991; Yamori, 1998; Buch and Lipponer, 2007; Claessens and van Horen, 2014a; 2014b; Huizinga, Voget and Wagner, 2014; Merz, Overesch and Wamser, 2015). Our work extends this growing literature as many of the non-bank financial institutions included in our sample would not be captured within these studies. Of this literature, a close paper to ours is Claessens and van Horen (2014a) who examine the impact of geographic and cultural distance on banking FDI finding that both deter investment. The negative effect of geographic distance in this paper also mirrors an earlier study by Buch (2005). The impact of international taxation on the volume of banking sector FDI is the focus of Huizinga, Voget and Wag- 
ner (2014). They provide evidence which shows that international double taxation of dividend income reduces banking sector FDI in terms of both foreign-bank assets and the number of banks.

\section{Data and Descriptive Statistics}

\subsection{Data}

To investigate the factors driving non-bank financial FDI location decisions, we construct a unique dataset using firm-level data from Bureau van Dijk's Amadeus database. These data report financial and ownership information based on standardised financial statements for companies across Europe. We use data from unconsolidated accounts and collect information on the firm's date and location of incorporation, number of employees, the location of the foreign investor and the firm's sector classification. Using primary four digit NACE Rev. 2 industrial classifications, we restrict our sample of firms to those classified in financial services, corresponding to NACE codes 6400-6630 inclusive (Table 1). ${ }^{15}$ This allows us to conduct a detailed sectoral analysis based on the firm's main activity with a specific focus on non-bank financial FDI.

Our dataset contains information on 8,724 new foreign affiliates across 27 European countries for the period 2004-2012. ${ }^{16}$ A firm is defined as foreign-owned if the firm has one foreign shareholder who holds 10 per cent equity capital. This definition is in line with international statistical frameworks used in balance of payments and international investment position statistics and reflects a lasting interest by a resident in one economy (the direct investor) in an enterprise resident in another economy. ${ }^{17} \mathrm{~A}$ foreign affiliate is defined as new in its year of incorporation.

\footnotetext{
${ }^{15}$ NACE is a statistical classification of economic activities developed in the European Community. NACE Rev. 2 was established by Regulation (EC) no. 1893/ 2006 of the European Parliament and of the Council on 20 December 2006.

${ }^{16}$ While a number of the countries in our sample were not Member States of the European Union (Czech Republic, Estonia, Cyprus, Latvia, Lithuania, Hungary, Malta, Poland, Slovakia and Slovenia joined the EU in May 2004 while Romania and Bulgaria joined in January 2007) at the start of our sample period, the new accession countries are only 7.84 per cent of the final sample of host countries. When we exclude these countries, our results are qualitatively similar.

${ }^{17}$ IMF (2013) Balance of Payments and International Investment Manual Sixth Edition (BPM6).
} 
We merge these firm-level data with country-level data which account for a host of gravity related characteristics (e.g. cultural, macroeconomic, geographical and institutional characteristics). These data are taken from a wide range of sources, including the World Bank, CEPII, the World Development Indicators (WDI) and the OECD. Drawing on the literature on location decisions we use a number of control variables as described in Section 5. The source and definition of each of these variables are presented in Table 2. In addition, some essential data cleaning was performed prior to conducting the empirical analysis. A description of the data construction and cleaning process is presented in Appendix 2.

\subsection{Descriptive Statistics}

Before proceeding to the regression analysis, it is instructive to gain an overview of the broad patterns in the data. The number of foreign affiliates in each NACE Rev.2 sector classification considered for this analysis is shown in Table 1. Almost 70 per cent of new foreign affiliates incorporated in Europe over our sample period relate to activities of financial holding companies. The second most prominent sector covers other financial services activities (except insurance and pension funding) which represents just over 10 per cent of our sample of firms. Although 27 European countries are included in our final sample, Table 3 shows that a small number of countries, including the Netherlands, the UK, Germany, France and Ireland represent almost 75 per cent of our total sample. The Netherlands was the chosen host for 38.5 per cent of foreign investments in the non-bank financial sector with almost 95 per cent of these investments in the Netherlands relating to activities of financial holding companies. ${ }^{18}$ Thus, FDI in this sector is remarkably concentrated.

\footnotetext{
${ }^{18} \mathrm{~A}$ number of factors may explain the large proportion of Dutch financial holding companies in our sample. As noted by the ECB (2014), 44 per cent of the euro area shadow banking system remains unallocated to a broad and unspecified sector. They estimate that entities located in the Netherlands and Luxembourg account for approximately two-thirds of this residual. For the Netherlands, entities are most likely special financial institutions (SFIs) which comprise two-thirds of the Dutch shadow banking sector (ECB, 2014). As documented by Broos et al. (2012), SFIs are set up by mainly NFCs for tax purposes, to attract external funding and to facilitate intragroup transactions. They suggest that most SFIs are classified as holding companies or group (finance) companies. Weyzig (2014) notes that there are approximately 12,000 of these entities located in the Netherlands which makes it the world's largest conduit country for FDI.
} 
The Amadeus database provides information on the Global Ultimate Owner (GUO) of the financial foreign affiliate which we use to identify the home country of FDI. A GUO is defined as an investor who holds over 50 per cent of the firm's equity capital. The GUO represents the home country for each foreign investment while their location can be identified by their ISO country code. We restrict our sample to firms who report their GUO ISO country code on Amadeus. ${ }^{19}$ Table 3 also provides information on the location of the GUO. The distribution is consistent with many of the related empirical studies (Barrios et al. 2012; Siedschlag et al. 2013a; 2013b; Lawless et al. 2015) and shows that OECD countries are the home country for the majority of GUOs. For instance, over 21 per cent of the firms in our sample originate in the United States followed by Luxembourg with 10 per cent, the UK with 7 per cent and Germany with 6 per cent.

Given the large proportion of financial holding companies in our sample, Table 4 presents the number of firms per country in this NACE Rev. 2 classification over the analysed period, 2004 to 2012. The first two columns show the top five host countries chosen as locations for financial holding companies. The Netherlands dominates with over 53 per cent followed by Germany (10.3 per cent) and the UK (7.9 per cent). Figure 2 displays the home country of the GUO for investments in financial holding companies in all countries as well as investors who set up financial holding companies in the Netherlands. It is noteworthy that the top home country for both samples is the United States. Table 4 also shows the top five host countries chosen as locations for all sectors excluding financial holding companies. Of the 2,737 foreign investments made excluding activities of financial holding companies, 22 per cent chose to locate in the UK followed by Ireland with almost 18.5 per cent and Germany with 15.8 per cent. ${ }^{20}$

By focusing specifically on non-bank financial FDI we can explore the nature of foreign investments in our sample and examine whether these investments create real economic activity in their host country or whether the investments are brass plate in

\footnotetext{
${ }^{19}$ Imposing such a restriction is required in order to introduce our gravity related control variables which use bilateral home and host country information. However, this restriction reduces the sample of firms available by 69 per cent owing to a large number of missing data for the GUO variable.

${ }^{20}$ Considering the home country of the GUO for foreign investments excluding the activities of financial holding companies shows a similar distribution with the United States again the main source of FDI followed by the UK.
} 
nature, such as the activities of SPVs. Currently, there is no single definition of or industrial classification for SPVs. However, according to the BIS (2009), they have a number of common features. First, they are usually created to perform a specific financial or business activity. Second, they are usually set up as bankruptcy remote vehicles which ensures that the assets within the SPV are protected from the risk of bankruptcy of the originator, and therefore creditors of the originator do not have a claim on the assets of the SPV. Third, SPVs usually do not have any direct employees and instead use professional corporate service providers, directors and trustees to perform the vehicle's duties. Fourth, SPVs may not have any physical presence or employees in their host country. Their only presence may be the address of their registered office. Fifth, in many European jurisdictions such as Ireland, the Netherlands and the UK, the most common type of SPVs are orphan vehicles (BIS, 2009). Orphan vehicles are entities whose share capital is a nominal amount and which is held beneficially on trust for a charity. The holding of shares on trust for charitable purposes ensures that the SPV is not owned by the originator (BIS, 2009).

With this in mind we will perform a number of cross-checks on our sample to isolate SPVs from foreign investments which support real economic activity. Since Q4 2009 the ECB has collected information on SPVs in the euro area whose primary activity is securitisation. The number and names of these securitisation vehicles in the euro area, defined as FVCs, are published on the ECB website. We cross-check our sample of foreign affiliates with a list of FVCs who have reported data to the ECB at any time from Q4 2009 to Q2 2014 inclusive. Using this approach, we identify just thirty FVCs within our sample of foreign affiliates. ${ }^{21}$

In addition, we use the number of employees as a proxy for 'real' economic activity, with firms that have no or little employment being in line with the common features of SPVs as discussed in BIS (2009). Table 5 shows the top host countries for firms with between one and ten employees. The Netherlands (with 47.9 per cent) is the top host

\footnotetext{
${ }^{21}$ It is noteworthy that a significant minority of the identified FVCs report having direct employees. In the absence of a euro area dataset for SPVs who fall outside the definition of FVCs, we cannot perform a cross-check on our dataset for these types of vehicles and therefore must rely on the number of employees as a proxy for real economic activity and as a means to filter out brass plate activities.
} 
location and given the concentration of non-bank financial FDI in activities of holding companies in the Netherlands, it suggests that the establishment of holding companies does create some economic activity in the host country (as proxied by the number of employees). Germany and the UK also attract financial investments which create some employment followed by Ireland and Austria. Next, we explore whether the ranking of host countries changes when we adjust the number of employees threshold to firms who report having greater than ten employees. Table 5 shows that the UK is the top host country for this more employment intensive FDI followed by the Netherlands. It is worth noting that the share of foreign investments who chose to locate in the Netherlands falls significantly (to 19 per cent) for this sub-sample of firms.

As our dataset covers new foreign affiliates which are established from 2004 to 2012, it allows us to explore whether the financial crisis has had an impact on the number of foreign affiliates being established in the non-bank financial sector in Europe. Considering the full sample of firms, Table 6 shows that the number of new financial foreign affiliates incorporated falls in 2009 which coincides with the economic crisis and a period of high uncertainty in Europe. However, in 2010 the number of new foreign affiliates incorporated rebounds to 1,154 firms which represents the second highest number of firms established per year over our sample period. This distribution is mirrored when we split our sample using firms who report that they employ between one and ten employees. It is noteworthy that when we consider just firms who have more than ten employees, the incorporation of new foreign affiliates in the non-bank financial sector has fallen every year since 2008 although our sample size for this category is much smaller.

\section{Empirical Methodology and Control Variables}

\subsection{Empirical Methodology}

Our empirical methodology employs the conditional logit model as proposed by McFadden (1974). This model has been widely used in the empirical literature to examine 
the determinants of firms' location decisions (Head, Ries and Swenson 1995; Head and Mayer 2004; Nefussi and Schwellnus 2010; Barrios et al. 2012; Siedschlag et al. 2013a; 2013b; Lawless et al. 2015). The firm chooses its location to maximise profits, where $\Pi_{i j t}$ is the profit of firm $i$ when locating in country $j$ at time $t$ :

$$
\Pi_{i j t}=X_{i j t} \beta+\varepsilon_{i j t}
$$

In this, $X_{i j t}$ is a vector of control variables including information about a potential host and the firm's home country and $\varepsilon_{i j t}$ is the error term. Although profits is unobserved directly, we do observe in which of the 27 European countries the firm locates. ${ }^{22}$ Therefore, our dependent variable, Location, is equal to one if the firm locates in a particular country $j$ and zero otherwise. Assuming the error term $\varepsilon_{i j t}$ follows a type 1 extreme value independent and identically distributed (i.i.d) across all foreign affiliates and countries, the probability of choosing a particular country $j$ can be written as follows: ${ }^{23}$

$$
P\left(Y=j \mid 1, \ldots, K, X_{i j}\right)=\frac{e^{X_{i j} \beta}}{\sum_{k=1}^{K} e^{X_{i k \beta}}}
$$

\subsection{Control Variables}

\subsubsection{Traditional Gravity Controls}

Drawing on the existing theoretical and empirical literature we include a number of control variables which are likely to effect expected profits from locating in a particular country. Gravity variables describe market size and market access and have been used extensively in the empirical FDI literature with common patterns emerging (see Blonigen and Piger (2011) for an overview). We proxy the size of the host market using In GDP. GDP growth is also included as a further proxy for macroeconomic conditions in the host country. The literature generally finds that both attract FDI. To account for

\footnotetext{
${ }^{22}$ In some specifications the number of alternatives falls below 26 owing to missing data for some combinations of countries and years.

${ }^{23}$ Inherent in this estimator, the i.i.d assumption imposes 'Independence of Irrelevant Alternatives (IIA)'. As is well known, this assumes that adding a new alternative cannot effect the relationship between a pair of existing alternatives.
} 
the wealth of the host country, we include Per Capita GDP. The typical estimate for this can be positive or negative depending on whether FDI is horizontal (where wealthier consumers attract FDI) or vertical (where high incomes translate to high costs, reducing FDI). In a similar vein, we include the unemployment rate. As highlighted by Siedschlag et al. (2013a), high unemployment rates can indicate a pool of available labour but may also reflect a lack of flexibility in the labour market or poor labour quality. Therefore, the effect of the unemployment rate on the location probability is ambiguous.

In addition, it is standard to account for the cultural, geographical and institutional characteristics of the host country. Distance, measured by kilometres between home and host capital cities, is used to proxy for factors which may hinder FDI between countries, such as information costs or time differences. We expect a negative effect on the probability of location choice. ${ }^{24}$ Similarly, we control for whether they share a common border (contiguity). To control for cultural barriers, we include a set of dummy variables describing whether the home and host countries share past colonial ties (colony), a common legal system (common legal), or a common language. ${ }^{25}$ We also include a dummy variable equal to one if they share a common currency (comcurr). In line with the existing literature, we expect all of these dummy variables to be positive. For example, Claessens and van Horen (2014a) include common language and legal system variables in their empirical analysis and find that they are important determinants of banking sector FDI. We anticipate that these factors are also important for non-bank financial FDI given the complexity of corporate structures and tax frameworks in this sector.

\subsubsection{Tax, Regulatory and Other Controls}

Beyond the traditional gravity variables, we expect that the regulatory policies of the host country have an impact on the location decision, particularly in this sector which

\footnotetext{
${ }^{24}$ The findings of Davies and Guillin (2014) validates the use of physical distance measures in empirical analyses on FDI in services.

${ }^{25}$ Melitz and Toubal (2014) explore alternative measures of linguistic similarity beyond the common language dummy, finding similar results for the different measures. In order to best compare our results to the existing work on FDI, we, however, proceed with this measure.
} 
is presumably rather mobile. The importance of tax on the location decisions of FDI has been the focus of much of the literature (Devereux and Griffith, 1998b; Barrios et al. 2012; Lawless et al. 2015) since corporation tax directly reduces the profits of firms. For our baseline, we use the statutory tax rate from KPMG. The advantage of this measure is its availability across countries. Its downside, however, is that relative to the effective average tax rate (EATR), it is less reflective of the actual taxes firms pay. Therefore, as a robustness check, we use the EATR measure collected by the Oxford University Centre for Business Taxation (which accounts for exemptions and other features of the tax code that affects the actual taxes paid). In any case, our two tax rate variables are highly correlated (0.949). Our a priori expectations is for a negative effect of taxation, with this marginal effect declining in the host tax rate (i.e. taxes matter more in low tax locations). ${ }^{26}$

Golub (2009) documents the restrictions in the services sector for a large sample of countries and finds that the financial sector is one of the most heavily restricted industries for foreign investment. Motivated by this literature, we control for the regulatory framework in place in the potential host country using OFFDIrestrict, the OECD's FDI restrictiveness index for the other financial services sector ${ }^{27}$ which is described in Kalinova, Palerm and Thomsen (2010). The index is a measure of all discriminatory measures affecting foreign investors and ranges from 0 (no impediments to FDI) to 100 (fully restricts FDI). The index covers four main areas including (i) foreign equity restrictions (ii) screening and prior approval requirements, (iii) rules for key personnel and (iv) other restrictions on the operation of foreign enterprises. Our theoretical prior is for a negative effect of FDI restrictions on the location probability. In order to proxy for the quality of the financial regulatory regime, we include an index which measures

\footnotetext{
${ }^{26}$ In unreported results, we also included a variable measuring the time it takes for the average firm to prepare its taxes. Although statistically significant, the marginal effect was economically unimportant. As including this variable impacted the number of observations, we have excluded it here.

${ }^{27}$ The 'other finance' sector includes securities and commodities brokerage, fund management and custodial services. As a robustness check, we also use the FDI restriction index for all industries and find similar results.
} 
restrictions on banks' securities, mutual funds, real estate and insurance activities. ${ }^{28}$ It is important to note, however, that a large proportion of the institutions within our sample (e.g. financial holding companies, financial leasing companies and SPVs) are outside of the regulatory perimeter in many EU Member States. Thus, it may have no impact or it may increase non-bank financial FDI if banking regulation is stringent in the host country.

Beyond these regulatory measures, we include two final variables relating to a country's attractiveness. First, we include private credit by deposit money banks and other financial institutions as a percentage of GDP as a measure of financial development. ${ }^{29}$ We do so as countries with deep financial development likely have characteristics that make them attractive to non-bank financial FDI. ${ }^{30}$ Second, we include the number of fixed broadband internet subscribers (per 100 people) as a proxy for infrastructure which may be particularly important for this services industry.

A number of our explanatory variables, namely unemployment, financial development and OFFDIrestrict are included with a lag of one time period to mitigate potential endogeneity concerns from possible simultaneity of these variables. Standard errors are robust to heteroskedasticity and clustered at the firm level. ${ }^{31}$ Table 7 displays summary statistics for the explanatory variables used in our empirical analysis. ${ }^{32}$ We observe significant variation in country characteristics, most notably with respect to GDP growth and the unemployment rate. The variation on GDP growth reflects the impact of the recent financial crisis on macroeconomic conditions in Europe where a number of countries, including Greece, Ireland, Portugal, Spain and Cyprus required external financial assistance programmes.

\footnotetext{
${ }^{28}$ In alternative specifications, we replace this variable with a dummy variable which is equal to one if the financial supervisor has the power to place a troubled bank into insolvency. Our results are broadly similar using this alternative measure for the quality of the financial regulatory regime.

${ }^{29}$ In alternative specifications, we include the number of commercial banks in the host country and find similar results.

${ }^{30}$ This can also proxy for agglomeration effects as per Head and Mayer (2004). Barry et al. (2003) discuss these alternative interpretations for manufacturing FDI into Ireland.

${ }^{31}$ We also compute heteroskedasticity-consistent standard errors and cluster at the country level which is in line with the methodology employed by Barrios et al. (2012). These estimates are not reported here, but are available, upon request, from the authors.

${ }^{32}$ Note that these are for the sample used in the preferred baseline specification.
} 


\section{Results}

Table 8 reports the baseline estimates of the conditional logit model. Column (1) reports the estimates from our initial specification which includes our full sample of firms. Of note is the statistically negative effect on statutory corporation tax rate. This finding contrasts with other studies of location choice determinants (Basile et al. 2008; Siedschlag et al. 2013b) who find an insignificant effect of the corporate tax rate on the location choice of MNEs. However, these studies do not consider FDI determinants of the financial sector. Lawless et al. (2015), however, do include financial sector firms and find that they are more responsive to changes in corporate tax rates than other sectors. Of the other country controls included, we find the standard results from the gravity variables.

Column (2) includes a number of additional control variables, particularly with respect to regulation. Note that the inclusion of these additional controls reduces our sample by approximately 17 per cent. Relative to the results in column (1), the primary change is that Per capita GDP is now significantly negative, suggesting that non-bank financial FDI avoids high income workers. In column (3), where we restrict the sample to those observations in (2) but do not include the additional controls, we see that this change is due to the new controls, not the change in sample. In line with the GDP growth variable, we find that higher unemployment reduces the probability of investment. This probability, however, is increasing in the size of the financial sector and internet usage. Regulation, be it with respect to FDI overall or to the financial sector, has a negative impact. This latter effect is notable as these firms generally fall outside the scope of these financial regulations. Finally, in line with Lawless et al. (2015), we see that the effect of the tax rate is non-linear, with higher tax rates reducing FDI by more for low-tax countries.

As noted above, the corporate tax rate variable is limited as it does not account for other features of the tax system. With this in mind, columns (4) and (5) replaces this measure with the EATR. On the whole, our results are comparable, although we find no significant evidence for a non-linear responsiveness to the tax rate. However, as can be 
seen, using this measure reduces our sample by nearly 30,000 observations. Owing to this data limitation, we proceed by using the statutory tax rate in our extended model specifications.

In Table 9 we arrive at our preferred specification by introducing the additional dummy variables proxying for barriers between the home and host countries. For comparison, column (1) repeats the specification from Table 8 (column (2)). To this, we add our gravity related explanatory variables such as sharing a common border, currency, colony, common legal system, and common language (column (2)). Sharing a common language, border, currency and legal system are found to increase the probability of firm location choice, with a shared colonial history having an unusual negative impact. ${ }^{33}$ Our other controls, however, remain as before. This then forms our preferred specification.

To this point we have examined the determinants of firm location decisions in the non-bank financial sector using our full sample of firms. However, as noted by the UNECE (2011), Claassen and van den Dool (2013), and the OECD (2014) amongst others, FDI statistics can be distorted by SPVs and holding companies used to channel capital through countries. Such round tripping of capital may be part of MNEs tax planning strategies or a way of circumventing regulations imposed in certain jurisdictions. Given our focus on non-bank financial FDI, these issues are particularly pertinent for our sample of firms. As displayed in our descriptive statistics in Table 6, a large proportion of our sample of firms relates to activities of brass plate entities which do not create sizeable economic activity in terms of employment. Therefore, in order to explore whether the determinants of location decisions are the same for FDI which creates employment and those which are brass plate in nature, we split our sample according to the number of employees reported by the firm. In column (3) of Table 9, we restrict our sample of firms to those who report having between one and ten employees. ${ }^{34}$ Note that with column (4) being larger employers, the number of observations

\footnotetext{
${ }^{33}$ As discussed below, this is driven by the United States and the UK.

${ }^{34}$ We also run this specification on sub-samples of firms who have no employees or who do not report employment data on Amadeus and obtain qualitatively similar results.
} 
falls significantly.

Comparing the results between columns (2) and (3) we find that, when looking at the low-employment firms, our results from the extended model are broadly unchanged. In column (4) however, we find much less significance. This may suggest that such firms are less sensitive to these factors. However, it must be noted that the sample size in column (4) is much smaller than column (3). As such, particularly as the sign of the estimated impact is generally the same in columns (3) and (4), this difference may be due to the smaller sample size.

As an alternative approach to firm size, in columns (5) and (6) we split our sample into small and large firms. To be classified as a large company, a company must fulfil one of the following criteria (i) annual turnover must be $€ 10$ million or more, or (ii) total assets must be $€ 20$ million or more, or (iii) the number of employees is greater than 150 (with small firms failing at least one of these criteria). Note that in contrast to the employment division in columns (3) and (4), this division has a larger number of observations for the large firms. As can be seen, we find very similar results for the two groups, something that further supports the notion that the insignificances in column (4) may be driven by sample size rather than differences in behaviour.

As described in Greene (2012) the coefficients in the conditional logit model are not directly tied to marginal effects. We therefore follow Head, Ries and Swenson (1995) and Head and Mayer (2004) and calculate average probability elasticities (APEs) which have been applied in a number of related empirical studies (Head, Ries and Swenson 1995; Head and Mayer 2004; Nefussi and Schwellnus 2010; Siedschlag et al. 2013a; 2013b). ${ }^{35}$ These are reported in Table 10. As can be seen, these indicate that (setting aside the insignificance of coefficients when considering firms with more than 10 employees) that the elasticities of the various factors is comparable across smaller and larger firms. Thus, combining the results we find that non-bank financial FDI behaves in ways comparable to other types of FDI: it is attracted to larger, fast-growing markets, is deterred by high labour costs, is restricted by the presence of geographic

\footnotetext{
${ }^{35}$ As noted by Nefussi and Schwellnus (2010), APEs are approximately equal to the estimated coeffiicients from the conditional logit model when there are a large number of choices in the choice set.
} 
and cultural barriers, avoids regulation, and seeks to minimise tax payments.

Finally, in Table 11 we conduct a number of additional robustness checks on our results using subsamples of the data. ${ }^{36}$ In column (1) of Table 11, we show that our results are robust to the exclusion of the observations of firms whose home country for FDI is outside the OECD. In column (2), we again limit our sample to firms whose home country is within the OECD. In addition, column (2) also excludes Ireland, Luxembourg, the Netherlands and Switzerland. Our motivation for excluding these home countries relates to ownership structures and FDI pertinent to the financial sector. As noted by Claassen and van den Dool (2013), these countries are prominent players in global headline FDI statistics despite having much smaller economies and financial centres compared to countries such as the Uinted States and UK and as such can act as a financial turntable in FDI transactions relating to SPVs. Therefore, headline FDI statistics for these countries are often distorted by these types of activity. Furthermore, some SPVs can be set up as orphan entities who shares are held on trust for charitable purposes. These charitable trusts are often registered in jurisdictions such as the Netherlands and Ireland which may potentially distort our GUO data (which is used to identify the home country of the FDI). We therefore control for such complex corporate structures used in these types of structured financial transactions by excluding these jurisdictions as home countries of FDI. Nevertheless, our main results are robust to their exclusion.

Furthermore, given the prominence of the United States as a source of FDI within our sample, we exclude the United States as a home country in column (3). The only significant difference is that now the unusual negative coefficient on the colonial variable disappears, suggesting that this unexpected finding was driven by the United States-UK pair. Column (4) shows our results when we limit the sample to firms whose

\footnotetext{
${ }^{36}$ Additionally, we estimate a series of cross-sectional regressions for each year of data in our sample. Furthermore, we run our regressions on pre-crisis and post-crisis years subsamples as a further modification of our data. In the majority of cases our results are unchanged. As a further robustness check, we estimate a nested logit model which relaxes the IIA assumption. While Hausman tests reject the assumption of IIA, the dissimilarity parameters are outside the normal range for some nests indicating inconsistency with utility maximisation. The results from the nested logit model are broadly similar to those obtained from our conditional logit model and as the vast majority of the location decisions literature use the conditional logit model, we do so as well for comparability.
} 
home country is within the EU28 (i.e. intra-EU FDI). As before, our main results hold, although contiguity and the overall FDI restrictiveness measure are now insignificant.

Next, we check our results by exploring heterogeneity across sectors within the non-bank financial sector. In column (5), the sample is restricted to financial NACE Rev. 2 sectors excluding the activities of financial holding companies. Given the large proportion of financial holding companies within our sample (almost 70 per cent), the number of observations in this specification falls significantly resulting in a drop in significance of the coefficients. However, we now find that the financial regulation and FDI restriction coefficients are now significantly positive. This suggests that it is primarily the holding companies that seek to avoid such regulation, with other firms being attracted to such features. Alternatively, as these sectors are typically not subject to these financial regulations, this may be evidence of MNEs choosing the incorporation of new non-bank financial institutions over other forms of financial FDI to circumvent heavy regulation. Outside of this change, however, we find that a broadly similar story as in the baseline.

Finally, in columns (6) and (7) we exclude two sets of home countries which may be particularly sensitive to taxation. In column (6), combining the categorisations of Lane and Milesi-Ferretti (2011) and Claessens and van Horen (2015), we exclude the following countries as offshore financial centres: Andorra, Antigua and Barbuda, Bahamas, Bahrain, Barbados, Bermuda, British Virgin Islands, Cayman Islands, Cyprus, Guernsey, Isle of Man, Jersey, Liechtenstein, Mauritius, Netherlands Antilles, Panama, Seychelles, and Singapore. Similarly, in column (7), following Davies et al. (2014), we exclude the Bahamas, Bermuda, Cayman Islands, Cyprus, Hong Kong, Ireland, Luxembourg, Malta, Singapore and Switzerland as tax havens. In both cases, the pattern of coefficients is broadly the same in terms of significance and magnitude. This suggests that our results are not being driven by either group of countries. 


\section{Conclusions}

Despite the substantial growth and complexity of corporate structures in the non-bank financial sector and their large impact on headline FDI statistics in some European countries, empirical studies focusing on FDI location decisions in this sector are scarce. This is due to a general lack of granular data for this sector. Motivated by these data gaps, we build a unique firm-level dataset in order to overcome this problem. In this paper, we explore the determinants of location decisions for new foreign affiliates in the non-bank financial sector in Europe over the period 2004-2012.

Our results suggest that the probability of a country being chosen to host non-bank financial FDI is driven by many of the factors that affect FDI generally, that is, it is increasing in market size, falling in barriers with the home country, and declining in regulation and taxes. Given the large proportion of brass plate activity within the sector, we separately consider these firms, finding that they behave much like the sector as a whole. Finally, we conduct a series of robustness checks using different sub-samples of firms to account for heterogeneity of determinants across different home countries of FDI, again finding consistency across groups.

While our results suggest that corporate taxes are a key factor in determining firms' location decisions, it also highlights the importance of traditional gravity controls such as sharing a common language and common legal system in determining non-bank financial FDI. Thus, concerns that this sector's investment will move en masse to low tax jurisdictions may be somewhat assuaged. In addition, our analysis provides insight into the nature of non-bank financial FDI in Europe. Owing to a lack of official granular data for this sector, our sample suggests a high level of concentration within a few countries while non-bank FDI is also dominated by a few sub-sectors, most notably, the activities of financial holding companies. This implies that, by appropriately targeting data collection, a significant proportion of the data gaps in the non-bank financial sector can be filled. 


\section{References}

Bakk-Simon, K., Borgioli, S., Giron, C., Hempell, H. S., Maddaloni, A., Recine, F., and Rosati, S. (2012), "Shadow banking in the euro area: an overview", Occasional Paper Series 133, European Central Bank.

Bank for International Settlements (BIS). Basel Committee on Banking Supervision, (2009), “The Joint Forum: Report on Special Purpose Entities”.

Barrios, S., Huizinga, H., Laeven, L., and Nicodème, G. (2012), “International taxation and multinational firm location decisions", Journal of Public Economics, 96(11), pp. 946-958.

Barry, F., Gorg, H., and Strobl, E. (2003), “Foreign direct investment, agglomerations, and demonstration effects: An empirical investigation", Review of World Economics, 139(4), pp. 583-600.

Barth, J. R., Caprio Jr, , G., and Levine, R. (2001), “The regulation and supervision of banks around the world - a new database", World Bank Policy Research Working Paper 2588, April 2001.

Basile, R., Castellani, D., and Zanfei, A. (2008), "Location choices of multinational firms in Europe: The role of EU cohesion policy", Journal of International Economics, 74(2), pp. 328-340.

Blonigen, B. A., and Piger, J. (2011), "Determinants of Foreign Direct Investment", NBER Working Papers 16704, National Bureau of Economic Research.

Broos, M., Carlier, K., Kakes, J., and Klaaijsen, E. (2012), "Shadow Banking: An Exploratory Study for the Netherlands", DNB Occasional Studies 1005, Netherlands Central Bank, Research Department.

Buch, C. M. (2005), “Distance and International Banking”, Review of International Economics, 13(4), pp. 787-804. 
Buch, C. M., and Lipponer, A. (2007), “FDI versus exports: Evidence from German banks", Journal of Banking and Finance, 31(3), pp. 805-826.

Claassen, P., and van den Dool, G. (2013), "The effects of including SPEs on BoP and FDI statistics", Paper prepared for the 26th Meeting of the IMF Committee on Balance of Payment Statistics, Oman, October 2013.

Claessens, S., and Ratnovski, L. (2014), “What is Shadow Banking?”, IMF Working Papers 14/25, International Monetary Fund.

Claessens, S., and van Horen, N. (2014a), "Location Decisions of Foreign Banks and Competitor Remoteness", Journal of Money, Credit and Banking, 46(1), pp. 145-170.

Claessens, S., and van Horen, N. (2014b), "Foreign Banks: Trends and Impact", Journal of Money, Credit and Banking, 46(s1), pp. 295-326.

Claessens, S., and van Horen, N. (2015), "The impact of the global financial crisis on banking globalization", DNB Working Papers 459, Netherlands Central Bank, Research Department.

Constâncio, V. (2015), "Financial stability risks, monetary policy and the need for macro-prudential policy ", Speech to the Warwick Economics Summit, 13 February 2015.

Creedon, C., Fitzpatrick, T., and Gaffney, E. (2012), “Ireland's External Debt: Economic and Statistical Realities", Economic Letters 12/EL/12, Central Bank of Ireland.

Davies, R. B., and Guillin, A. (2014), “How Far Away is Intangible? Services FDI and Distance", The World Economy, 37(12), pp. 1731-1750.

Davies, R. B., Martin, J., Parenti, M., and Toubal, F. (2014), “Knocking on Tax Haven's Door: Multinational Firms and Transfer Pricing", Working Papers 2014-21, CEPII research center. 
Devereux, M.P., and Griffith, R. (1998a), “The taxation of discrete investment choices”, IFS Working Paper W98/16, Institute for Fiscal Studies.

Devereux, M.P., and Griffith, R. (1998b), “Taxes and the location of production: evidence from a panel of US multinationals", Journal of Public Economics, 68(3), pp. $335-367$.

ECB (2014), “Banking Structures Report”, October 2014.

European Commission (2015), “Building a Capital Markets Union”, Green Paper, COM (2015) 63, Brussels, February 2015.

Financial Stability Board (FSB). (2013), "Strengthening Oversight and Regulation of Shadow Banking: An Overview of Policy Recommendations", August 2013.

Goldberg, L. (2007), "Financial Sector FDI and Host Countries: New and Old Lessons", Economic Policy Review, 13(1), pp. 1-17, Federal Reserve Bank of New York.

Golub, S. (2009), “Openness to Foreign Direct Investment in Services: An International Comparative Analysis", The World Economy, 32(8), pp. 1245-1268.

Greene, W. (2012), "Econometric Analysis", (Seventh Edition ed.). Pearson.

Grosse, R., and Goldberg, L. G. (1991), “Foreign bank activity in the United States: An analysis by country of origin", Journal of Banking and Finance, 15(6), pp. 1093-1112.

Head, K., and Mayer, T. (2004), "Market Potential and the Location of Japanese Investment in the European Union", The Review of Economics and Statistics, 86(4), pp. 959-972.

Head, K., Ries, J., and Swenson, D. (1995), "Agglomeration benefits and location choice: Evidence from Japanese manufacturing investments in the United States", Journal of International Economics, 38(3-4), pp. 223-247.

Hebous, S., Ruf, M., and Weichenrieder, A. J. (2011),“The Effects Of Taxation On The Location Decision Of Multinational Firms: M\&A Versus Greenfield Invest- 
ments," National Tax Journal, National Tax Association, vol. 64(3), pages 817-38, September.

Huizinga, H., Voget, J., and Wagner, W. (2014), “International Taxation and CrossBorder Banking", American Economic Journal: Economic Policy, American Economic Association, 6(2), pp. 94-125.

International Monetary Fund (2013), Balance of Payments Manual 6th Edition.

International Monetary Fund (IMF). (2014), "Shadow Banking around the Globe: How Large, and How Risky?", In Global Financial Stability Report. World Economic and Financial Surveys, Washington, October.

Kalinova, B., Palerm, A., and Thomsen, S. (2010), “OECD's FDI Restrictiveness Index: 2010", OECD Working Papers on International Investment 2010/3, OECD Publishing.

Lane, P. R., and Milesi-Ferretti, G.M. (2011), “Cross-Border Investment in Small International Financial Centres", International Finance, Wiley Blackwell, vol. 14(2), pages 301-330, 06 .

Lawless, M., McCoy, D., Morgenroth, E., and O'Toole, C. (2015), “Corporate Tax and Location Choice of Multinational Firms", MPRA Paper 64769, University Library of Munich, Germany.

McFadden, D. (1974), "Frontiers in Econometrics", In P. Zarembka (Ed.) Academic Press, New York.

Melitz, J., and Toubal, F. (2014), “Native language, spoken language, translation and trade", Journal of International Economics, Elsevier, vol. 93(2), pages 351-363.

Merz, J., Overesch, M., and Wamser, G. (2015), “Tax vs. Regulation Policy and the Location of Financial Sector FDI", CESifo Working Paper Series 5500, CESifo Group Munich. 
Moutot, P., Gerdesmeier, D., Lojschová. A and Landesberger, J. V. (2007), “The role of other financial intermediaries in monetary and credit developments in the euro area", Occasional Paper Series 75, European Central Bank.

Nefussi, B., and Schwellnus, C. (2010), "Does FDI in manufacturing cause FDI in business services? Evidence from French firm-level data", Canadian Journal of Economics, 43 (1) pp. 180-203.

OECD (2014), “FDI in Figures”, April 2014.

Ostry, J. D., Ghosh, A.R., Habermeier, K., Chamon, M., Qureshi, M.S., and Reinhardt, D.B.S. (2010), “Capital Inflows: The Role of Controls", IMF Staff Position Note 10/0, International Monetary Fund.

Siedschlag, I., Zhang, X., and Smith, D. (2013a), “What determines the location choice of multinational firms in the information and communication technologies sector?", Economics of Innovation and New Technology, 22(6), pp. 581-600.

Siedschlag, I., Smith, D., Turcu, C., and Zhang, X. (2013b), "What determines the location choice of R\&D activities by multinational firms?", Research Policy, 42, pp. 1420-1430.

UNECE (2011), "Impact of Globalisation on National Accounts”, Conference of European Statisticians, Note by UNECE Secreatariat, Geneva 14-16 June 2011.

Weyzig, F. (2014), “The Capital Structure of Large Firms and the Use of Dutch Financing Entities", Fiscal Studies, Institute for Fiscal Studies, 35 (6) pp. 139-164.

Yamori, N. (1998), "A note on the location choice of multinational banks: The case of Japanese financial institutions", Journal of Banking and Finance, 22 (1) pp. 109-120. 


\section{Appendix 1: Glossary of Terms}

Finance company: Finance companies are institutional units primarily engaged in the extension of credit to NFCs and households. Source: OECD Online Glossary of Statistical Terms.

Financial auxiliary: A corporation or quasi-corporation that is engaged primarily in auxiliary financial activities, e.g. insurance brokers, investment advisors and corporations providing infrastructure for financial markets. Source: ECB Statistics Glossary.

Financial corporations engaged in lending: Corporations and quasi-corporations, classified as OFIs, specialising mainly in asset financing for households and NFCs. Included are also firms specialising in financial leasing, factoring, mortgage lending and consumer lending. Source: ECB Statistics Glossary.

Financial holding company: Financial holding companies are entities that are principally engaged in controlling financial corporations or groups of subsidiary financial corporations and do not conduct the business of such financial corporations themselves. Source: Moutot et al. (2007).

Financial leasing company: Financial leasing companies engage in financing the purchase of tangible assets. The leasing company is the legal owner of the goods, but ownership is effectively conveyed to the lessee, who incurs all benefits, costs and risks associated with ownership of the assets. Source: OECD Online Glossary of Statistical Terms.

Financial vehicle corporation (FVC): An FVC is an entity whose principal activity meets the following criteria: it carries out securitisation transactions and is insulated from the risk of bankruptcy or any other default of the originator. It issues securities, securitisation fund units, other debt instruments and/ or financial derivatives and/ or legally or economically own assets underlying the issue of securities, seucritisation fund units, other debt instruments and/ or financial derivatives that are offered for sale to the public or sold on basis of private placements. Source: Moutot et al. (2007).

Monetary financial institution (MFI): MFIs are resident credit institutions as defined in EU law, and other resident financial institutions whose business is to receive deposits and / or close substitutes for deposits from entities other than MFIs, and for their own account (at least in economic terms) to grant credits and/ or make investments in securities. MFIs include central banks, credit institutions, other deposit-taking corporations and money market funds (MMFs). Source: ECB Statistics Glossary. 
Other financial intermediary (OFI): A corporation or quasi-corporation other than an insurance corporation or pension fund that is engaged mainly in financial intermediation by incurring liabilities in forms other than currency, deposits, and/ or close substitutes for deposits from institutional entities other than MFIs, in particular those engaged in long-term financing such as corporations engaged in financial leasing, FVCs created to be holders of securitised assets, dealers in securities and derivatives (when dealing for their own account), venture capital corporations and development capital companies. Source: ECB Statistics Glossary.

Securities and derivative dealers: Securities and derivative dealers are firms that provide investment services for clients through brokerage, investing or market-making in securities and derivatives as their own business. The investment services provided include asset management advice, clearing and custody services as well as the buying and selling of financial instruments for the sole purpose of benefiting from the margin between the acquisition and selling price. Source: Moutot et al. (2007).

Securitisation: The pooling of financial assets, such as residential mortgage loans, and their subsequent sale to a special-purpose vehicle, which then issues fixed income securities for sale to investors. The principal and interest of these securities depend on the cash flows produced by the pool of underlying financial assets. Source: ECB Statistics Glossary.

Shadow banking: The Financial Stability Board (FSB) define shadow banking as "credit intermediation involving entities and activities outside the regular banking system" or non-bank credit intermediation in short (FSB, 2013). However, there are a number of alternative definitions of shadow banking applied in the academic literature. For example, Claessens and Ratnovski (2014) propose to define shadow banking as "all financial activities, except traditional banking, which require a private or public backstop to operate."

Special purpose vehicle (SPV): An SPV is a legal entity set up by a sponsoring firm. The sponsor is usually a bank, finance company or insurance company. SPVs can be set up for a number of reasons including (but not limited to): the transfer of credit or interest rate risk, as a source of funding, to take advantage of tax or regulatory arbitrage opportunities which may exist and for balance sheet management. Source: BIS (2009).

Although there is no internationally agreed definition of an SPV, the following characteristics are typical (BIS, 2009). They are usually:

- created for a single business purpose or activity;

- set up to have no employees;

- set up to be bankruptcy remote, often using an orphan entity structure (whereby the share capital is held on trust); 
- managed by employees of corporate service providers;

- set up with a nominal amount of share capital which usually does not support the SPV'S overall activities;

- funded through the issuance of debt securities.

- brass plate in nature with no physical presence at their address of incorporation. 


\section{Appendix 2: Data Cleaning, Figures and Tables}

This section describes the data search criteria for obtaining our sample of firms on Amadeus. Prior to conducting our empirical analysis some essential data cleaning was performed. The search strategy was as follows:

- Firms classified as "active" on Amadeus;

- Firms corresponding to NACE Rev.264 (financial services activities, except insurance and pension funding), 65 (insurance, reinsurance and pension funding, except compulsory social security) and 66 (activities auxiliary to financial services and insurance);

- Firms incorporated in EU 28 countries (Austria, Belgium, Bulgaria, Croatia, Cyprus, Czech Republic, Germany, Denmark, Estonia, Spain, Finland, France, UK, Greece, Hungary, Ireland, Italy, Latvia, Lithuania, Luxembourg, Malta, the Netherlands, Poland, Portugal, Romania, Sweden, Slovenia and Slovakia).

- Firms with at least one foreign shareholder (owning 10 per cent equity) located in another country;

- Firms with unconsolidated financial accounts;

- Firms who were newly incorporated between 2004 and 2012 inclusive.

Based on the search criteria outlined above, Amadeus identifies just over 40,000 firms. However, we impose a number of essential data filters. First, we restrict our sample to firms whose GUO can be identified on Amadeus. Imposing such a restriction is required in order to introduce our gravity related control variables which use bilateral home and host country information. However, this restriction reduces the sample of firms available on Amadeus by 69 per cent owing to a large number of missing data for the GUO variable. Second, we convert our data to long format which results in 27 observations per firm (26 zeros and a dummy variable equal to one if that country was the chosen location of the firm).

Third, we merge our firm-level data with country-specific controls (from various sources including the World Bank, Thomson Reuters Datastream and KPMG) and gravity controls (taken from CEPII's Gravity dataset). Owing to missing data for some bilateral pairs in the CEPII Gravity dataset, 7,209 observations out of 329,859 observations were dropped representing just 2.2 per cent of our final sample. The latest year covered by the CEPII Gravity dataset refers to 2006. Therefore, some countries included in our sample, namely Cyprus, Estonia, Latvia, Lithuania, Slovenia and Slovakia may be recorded as not sharing a common currency with other euro area Member States for the years 2007-2012 owing to the fact that these countries joined the euro area after 2006. However, such a data limitation should not affect our estimations as only 2 per cent of firms in our final sample located in these six countries. Fourth, 
we exclude Croatia from our analysis due to missing data for a number of our explanatory variables. Croatia represents a very small percentage of our final sample owing to the fact that only 16 firms were incorporated over our sample period once our data cleaning filters are applied. 
FIGURE 1. Breakdown of euro area investment funds and OFIs by type, per cent of total assets Q1 2015

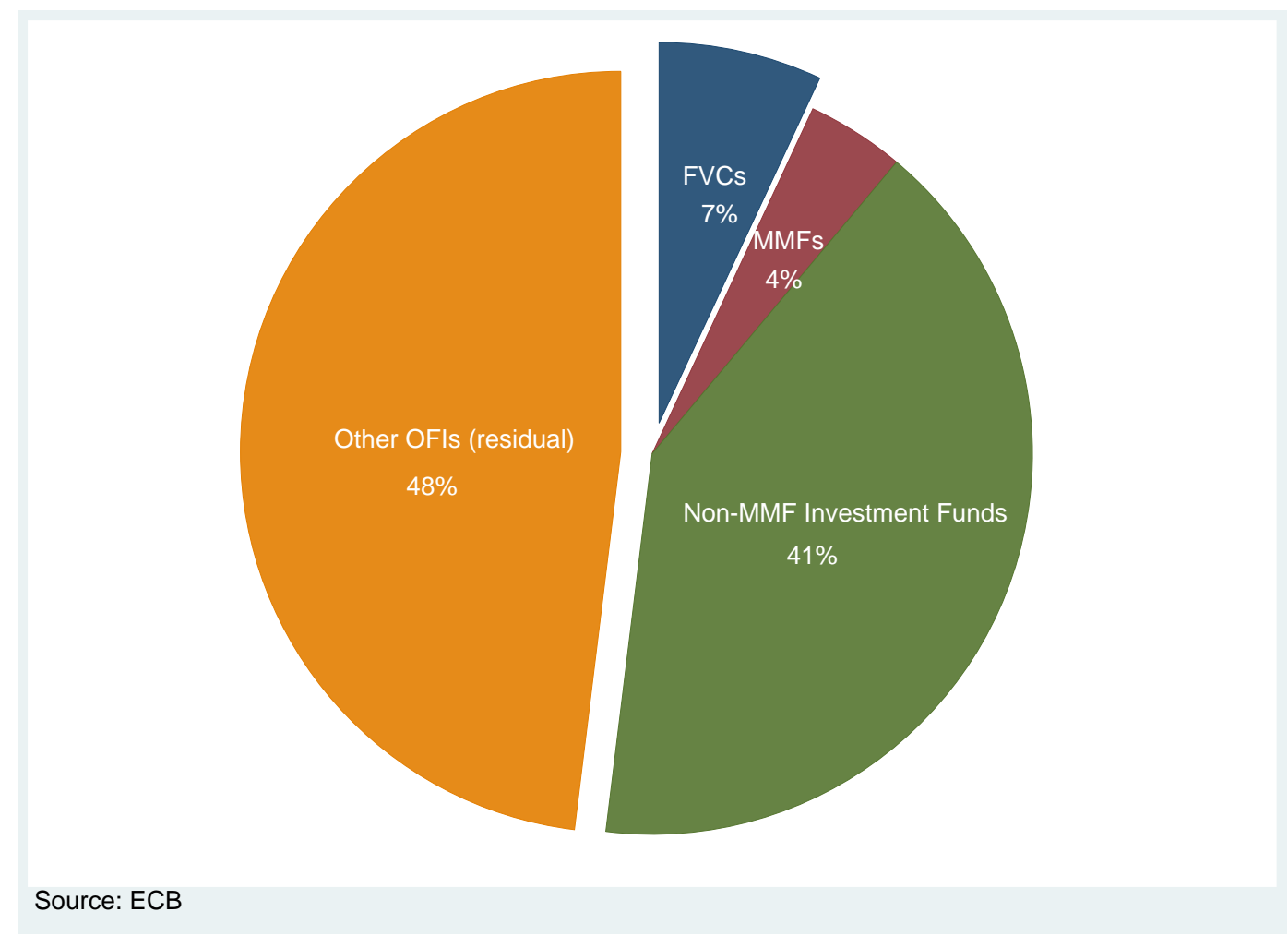

FIGURE 2. Home country of top five foreign investors in financial holding companies incorporated in the EU and the Netherlands, 2004-2012

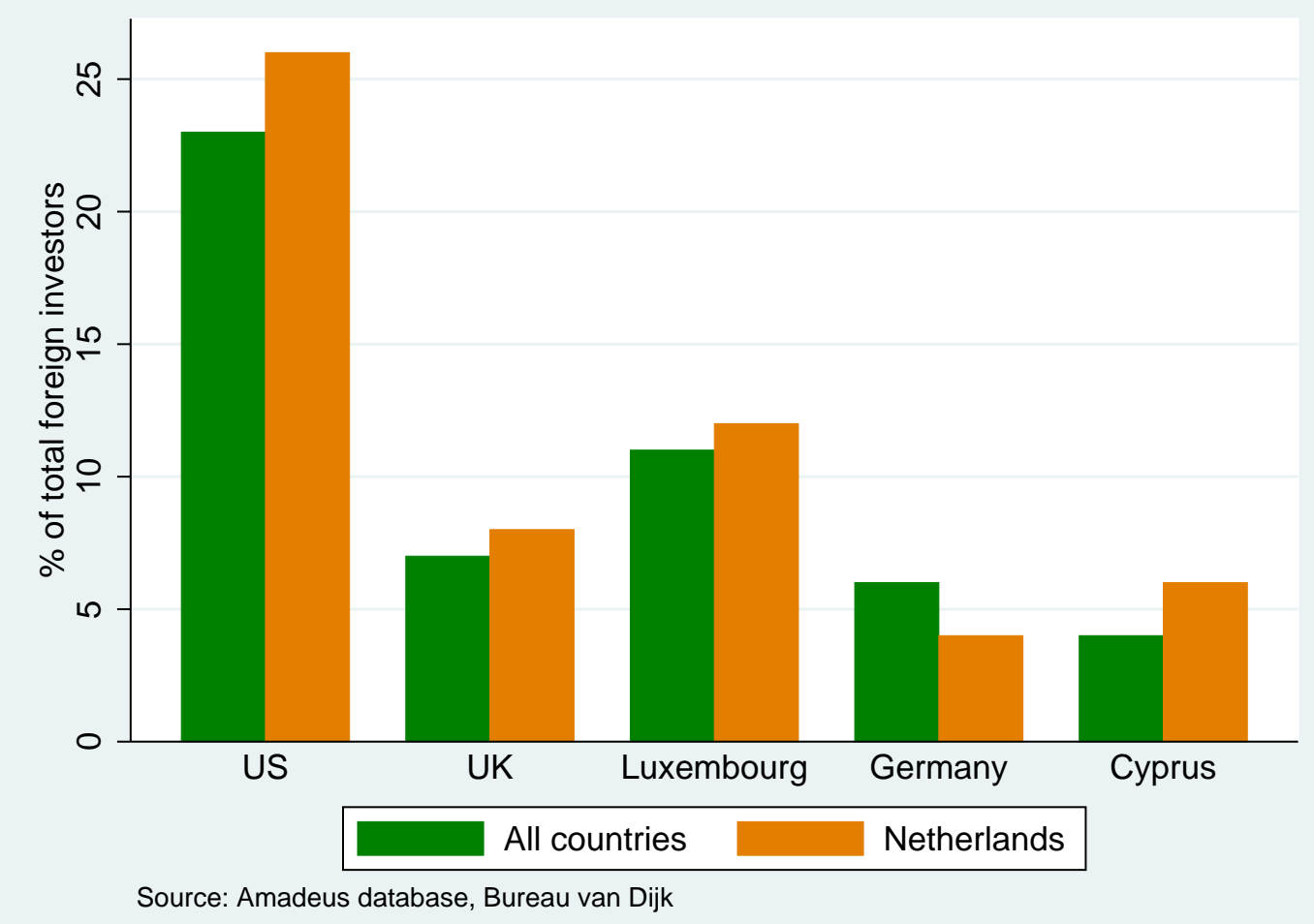


TABLE 1. NACE Rev. 2 classification and number of non-bank financial foreign affiliates per NACE classification

\begin{tabular}{|c|c|c|}
\hline NACE Rev. 2 Code/ Description & $\overline{\mathbf{N}}$ & \% of total sample \\
\hline \multicolumn{3}{|l|}{64 Financial services activities, except insurance and pension funding } \\
\hline 6411 Central banking & 0 & 0 \\
\hline 6419 Other monetary intermediation & 0 & 0 \\
\hline 6420 Activities of holding companies ${ }^{\dagger}$ & 5,987 & 68.5 \\
\hline 6430 Trusts, funds and similar entities ${ }^{\dagger}$ & 323 & 3.7 \\
\hline 6491 Financial leasing ${ }^{\dagger}$ & 213 & 2.4 \\
\hline 6492 Other credit granting ${ }^{\dagger}$ & 0 & 0 \\
\hline $\begin{array}{l}6499 \text { Other financial services activities, } \\
\text { except insurance and pension funding }\end{array}$ & 882 & 10.1 \\
\hline \multicolumn{3}{|l|}{66 Activities auxiliary to financial services and insurance } \\
\hline 6611 Administration of financial markets* & 74 & 0.8 \\
\hline 6612 Security and commodity contracts brokerage* & 202 & 2.3 \\
\hline \multicolumn{3}{|l|}{6619 Other activities auxiliary to financial services } \\
\hline except insurance and pension funding* & 689 & 7.9 \\
\hline 6621 Risk and damage evaluation* & 26 & 0.3 \\
\hline 6622 Activities of insurance agents and brokers* & 150 & 1.8 \\
\hline 6629 Other activities auxiliary to insurance and pension funding* & 62 & 0.7 \\
\hline 6630 Fund management activities* & 116 & 1.3 \\
\hline Total & 8,724 & 100 \\
\hline
\end{tabular}

Note: Banks and insurance company accounts are not available on the Amadeus database. Therefore entities relating to NACE Rev. 265 insurance, reinsurance and pension funding, except compulsory social security are not covered in our sample.

$\dagger$ refers to NACE Rev. 2 sectors which are classified as other financial intermediaries. Under ESA 2010, financial holding companies have been reclassified as captive financial institutions and money lenders. * refers to NACE Rev. 2 sectors which are classified as financial auxiliaries. 
TABLE 2. Variable Definitions and Data Sources

Variable

Location

Comcurr

Common legal

Com language

Contiguity

Corporation Tax

Corp. Tax2

EATR

EATR2

Fin. Regulation

Fin. Development

GDP growth

Internet

Ln Distance

Ln GDP

OFFDIrestrict

Per Capita GDP

Unemployment Rate
Description

Dummy variable equal to 1 if affiliate is located

Data Source

Amadeus

in a country and 0 otherwise

Dummy variable equal to 1 if home and host

CEPII

country ever shared a colonial relationship and

0 otherwise

Dummy variable equal to 1 if home and host

CEPII

country share a common currency and 0

otherwise

Dummy variable equal to 1 if home and host

country share a common legal system and 0

otherwise

Dummy variable equal to 1 if home and host

CEPII

country share a common language

Dummy variable equal to 1 if home and host

CEPII

country share a common border and 0 otherwise

Statutory corporation tax rate, per cent

KPMG

Squared term of statutory corporation tax rate,

KPMG

per cent

Effective Average Tax Rate as per Devereux and

CBT Tax Database Griffith (1998a)

Squared term effective Average Tax Rate as per

CBT Tax Database Griffith and Devereux (1998a)

Restriction index on banks' activities in

Barth et al. (2001)

securities, mutual funds, insurance and real

estate activities. Higher values indicate more

intensive restrictions

Private credit by deposit money banks and

other financial institutions as a percentage of

GDP

Annual GDP growth, per cent

WDI

Fixed broadband internet subscribers (per 100

WDI

people)

Log of distance, measured by $\mathrm{km}$ between host

CEPII

and home country capital cities, weighted by

population

Log of GDP, constant 2005 prices US Dollars

WDI

A measure of all discriminatory measures

OECD

affecting foreign investors in the other financial

sector. Varies from 0 (no impediments) to 100

(fully restricts)

GDP per capita in host country

WDI

Rate of country unemployment, per cent
Datastream 
TABLE 3. Home and host countries of new non-bank financial foreign affiliates incorporated in the EU, 2004-2012

\begin{tabular}{llc|llc}
\hline \hline $\begin{array}{l}\text { Top 10 } \\
\text { Host Countries }\end{array}$ & $\mathbf{N}$ & $\mathbf{\%}$ & $\begin{array}{l}\text { Top 10 } \\
\text { Home Countries }\end{array}$ & $\mathbf{N}$ & $\mathbf{\%}$ \\
\hline Netherlands & 3,363 & 38.5 & United States & 1,854 & 21.2 \\
United Kingdom & 1,073 & 12.3 & Luxembourg & 842 & 9.7 \\
Germany & 1,047 & 12.0 & United Kingdom & 629 & 7.2 \\
France & 522 & 6.0 & Germany & 525 & 6.0 \\
Ireland & 505 & 5.8 & Netherlands & 372 & 4.3 \\
Belgium & 326 & 3.7 & Switzerland & 343 & 3.9 \\
Austria & 260 & 3.0 & Cyprus & 342 & 3.9 \\
Italy & 214 & 2.5 & France & 280 & 3.2 \\
Denmark & 202 & 2.3 & Belgium & 233 & 2.7 \\
Spain & 193 & 2.2 & Austria & 170 & 1.9 \\
\hline Total & 8,724 & & Total & 8,724 & \\
\hline \hline
\end{tabular}

Source: Authors' calculations.

TABLE 4. The location of new financial holding companies and new non-bank financial foreign affiliates (excluding financial holding companies) incorporated in the EU, 2004-2012.

\begin{tabular}{llc|llc}
\hline \hline $\begin{array}{l}\text { Top 5 } \\
\text { Host Countries } \\
\text { of financial holding } \\
\text { companies }\end{array}$ & $\mathbf{N}$ & $\mathbf{\%}$ & $\begin{array}{l}\text { Top 5 } \\
\text { Host Countries } \\
\text { (excluding financial } \\
\text { holding companies) }\end{array}$ & N & \% \\
\hline Netherlands & 3,194 & 53.4 & United Kingdom & 602 & 22.0 \\
Germany & 614 & 10.3 & Ireland & 505 & 18.5 \\
United Kingdom & 471 & 7.9 & Germany & 433 & 15.8 \\
France & 388 & 6.5 & Netherlands & 169 & 6.2 \\
Belgium & 281 & 4.7 & France & 134 & 4.9 \\
\hline Total & 5,987 & & Total & 2,737 & \\
\hline \hline
\end{tabular}

Source: Authors' calculations. 
TABLE 5. The location of new non-bank financial foreign affiliates located in the EU by number of employees, 2004-2012.

\begin{tabular}{|c|c|c|c|c|c|}
\hline $\begin{array}{l}\text { Top } 5 \\
\text { Host Countries } \\
\text { of Firms with } \\
\text { 1-10 employees }\end{array}$ & $\overline{\mathbf{N}}$ & $\%$ & $\begin{array}{l}\text { Top } 5 \\
\text { Host Countries } \\
\text { of Firms with } \\
>10 \text { employees }\end{array}$ & $\overline{\mathbf{N}}$ & $\overline{~ \%}$ \\
\hline Netherlands & 1,282 & 47.9 & United Kingdom & 82 & 21.8 \\
\hline Germany & 467 & 17.4 & Netherlands & 72 & 19.1 \\
\hline United Kingdom & 251 & 9.4 & Germany & 34 & 9.0 \\
\hline Ireland & 99 & 3.7 & Spain & 26 & 6.9 \\
\hline Austria & 92 & 3.4 & Ireland & 24 & 6.4 \\
\hline Total & 2,679 & & Total & 377 & \\
\hline
\end{tabular}

Source: Authors' calculations.

TABLE 6. Number of new financial foreign affiliates in the EU by year of incorporation, 2004-2012

\begin{tabular}{lccc}
\hline \hline & All firms & $\begin{array}{c}\text { Firms with } \\
\text { 1-10 employees }\end{array}$ & $\begin{array}{c}\text { Firms with } \\
\text { 10 employees }\end{array}$ \\
\hline Year & $\mathbf{N}$ & $\mathbf{N}$ & $\mathbf{N}$ \\
\hline 2004 & 636 & 171 & 58 \\
2005 & 802 & 232 & 48 \\
2006 & 1,105 & 329 & 44 \\
2007 & 1,356 & 425 & 52 \\
2008 & 1,086 & 348 & 52 \\
2009 & 893 & 275 & 44 \\
2010 & 1,154 & 392 & 38 \\
2011 & 1,038 & 351 & 21 \\
2012 & 654 & 156 & 20 \\
\hline Total & 8,724 & 2,679 & 377 \\
\hline \hline
\end{tabular}

Source: Authors' calculations. 
TABLE 7. Summary statistics

\begin{tabular}{lccccc}
\hline \hline \multicolumn{1}{c}{ Variable } & $\mathbf{N}$ & Mean & Std. Dev & Min. & Max. \\
\hline Colony & 191160 & 0.1 & 0.2 & 0 & 1.0 \\
Comcurr & 191160 & 0.2 & 0.4 & 0 & 1.0 \\
Com language & 191160 & 0.1 & 0.3 & 0 & 1.0 \\
Common legal & 191160 & 0.2 & 0.4 & 0 & 1.0 \\
Contiguity & 191160 & 0.1 & 0.3 & 0 & 1.0 \\
Corporation Tax & 191160 & 24.9 & 6.6 & 12.5 & 38.4 \\
Corp. Tax2 & 191160 & 660.3 & 327.3 & 156.3 & 1471.5 \\
EATR & 166414 & 22.6 & 5.5 & 11.1 & 34.0 \\
EATR2 & 166414 & 542.6 & 244.4 & 122.9 & 1156.7 \\
Fin. Regulation & 191160 & 6.0 & 1.0 & 4.0 & 8.0 \\
Fin. Development & 191160 & 108.7 & 52.4 & 27.0 & 227.5 \\
GDP growth & 191160 & 1.9 & 4.2 & -18.0 & 12.2 \\
Internet & 191160 & 20.6 & 9.0 & 0.5 & 39.8 \\
Ln Distance & 191160 & 7.8 & 1.1 & 5.1 & 9.9 \\
Ln GDP & 191160 & 26.2 & 1.5 & 23.3 & 28.8 \\
Per Capita GDP & 191160 & 10.1 & 0.6 & 8.7 & 11.4 \\
OFFDIrestrict & 191160 & 3.8 & 4.9 & 0 & 20.5 \\
Unemploy. Rate & 191160 & 8.4 & 3.7 & 3.1 & 21.4 \\
\hline
\end{tabular}


TABLE 8. Estimates of Conditional Logit Model for Non-Bank Financial Firms' Location Decisions (Baseline Model)

\begin{tabular}{|c|c|c|c|c|c|}
\hline Variable & (1) & (2) & (3) & (4) & (5) \\
\hline & $\begin{array}{c}\text { Full } \\
\text { Sample }\end{array}$ & $\begin{array}{c}\text { Full } \\
\text { Sample }\end{array}$ & $\begin{array}{l}\text { Sample } \\
\text { from (2) }\end{array}$ & $\begin{array}{l}\text { Sample } \\
\text { from (2) }\end{array}$ & $\begin{array}{l}\text { Sample } \\
\text { from (2) }\end{array}$ \\
\hline $\operatorname{Ln}$ GDP $(+)$ & $\begin{array}{c}0.706^{* * *} \\
(0.012)\end{array}$ & $\begin{array}{c}0.743^{* * *} \\
(0.019)\end{array}$ & $\begin{array}{c}0.758^{* * *} \\
(0.011)\end{array}$ & $\begin{array}{c}0.954^{* * *} \\
(0.012)\end{array}$ & $\begin{array}{l}1.101^{* * *} \\
(0.022)\end{array}$ \\
\hline Per Capita GDP (+) & $\begin{array}{c}0.941^{* * *} \\
(0.029)\end{array}$ & $\begin{array}{c}-1.037^{* * *} \\
(0.057)\end{array}$ & $\begin{array}{c}1.076^{* * *} \\
(0.034)\end{array}$ & $\begin{array}{c}1.434^{* * *} \\
(0.043)\end{array}$ & $\begin{array}{l}-0.143^{*} \\
(0.069)\end{array}$ \\
\hline GDP growth $(+)$ & $\begin{array}{c}0.032^{* * *} \\
(0.007)\end{array}$ & $\begin{array}{c}0.122^{* * *} \\
(0.011)\end{array}$ & $\begin{array}{c}0.031^{* * *} \\
(0.007)\end{array}$ & $\begin{array}{c}0.010 \\
(0.007)\end{array}$ & $\begin{array}{c}0.048^{* * *} \\
(0.010)\end{array}$ \\
\hline Ln Distance (-) & $\begin{array}{c}-1.574^{* * *} \\
(0.030)\end{array}$ & $\begin{array}{c}-1.318^{* * *} \\
(0.038)\end{array}$ & $\begin{array}{c}-1.657^{* * *} \\
(0.031)\end{array}$ & $\begin{array}{c}-1.583^{* * *} \\
(0.033)\end{array}$ & $\begin{array}{c}-1.172^{* * *} \\
(0.040)\end{array}$ \\
\hline Corporation Tax (-) & $\begin{array}{c}-0.065^{* * *} \\
(0.002)\end{array}$ & $\begin{array}{c}-0.313^{* * *} \\
(0.018)\end{array}$ & $\begin{array}{c}-0.074^{* * *} \\
(0.0019)\end{array}$ & & \\
\hline Corp. Tax2 (+) & & $\begin{array}{c}0.005^{* * *} \\
(0.000)\end{array}$ & & & \\
\hline Unemploy. Rate Ra-1 $_{t}(?)$ & & $\begin{array}{c}-0.096^{* * *} \\
(0.007)\end{array}$ & & & $\begin{array}{c}-0.070^{* * *} \\
(0.007)\end{array}$ \\
\hline Fin. Development $t_{t-1}(+)$ & & $\begin{array}{c}0.012^{* * *} \\
(0.000)\end{array}$ & & & $\begin{array}{l}0.010^{* * *} \\
(0.000)\end{array}$ \\
\hline OFFDIrestrict $_{t-1}(-)$ & & $\begin{array}{c}-0.030^{* * *} \\
(0.004)\end{array}$ & & & $\begin{array}{c}-0.098^{* * *} \\
(0.005)\end{array}$ \\
\hline Internet $(+)$ & & $\begin{array}{c}0.083^{* * *} \\
(0.004)\end{array}$ & & & $\begin{array}{l}0.033^{* * *} \\
(0.005)\end{array}$ \\
\hline Fin. Regulation (-) & & $\begin{array}{c}-0.198^{* * *} \\
(0.018)\end{array}$ & & & $\begin{array}{c}-0.285^{* * *} \\
(0.020)\end{array}$ \\
\hline $\operatorname{EATR}(-)$ & & & & $\begin{array}{c}-0.116^{* * *} \\
(0.002)\end{array}$ & $\begin{array}{l}-0.072^{* *} \\
(0.025)\end{array}$ \\
\hline EATR2 (+) & & & & & $\begin{array}{c}-0.000 \\
(0.001)\end{array}$ \\
\hline$N$ & 230949 & 191160 & 191160 & 161422 & 161422 \\
\hline Firms & 8724 & 8519 & 8519 & 8264 & 8264 \\
\hline Log-pseudolikelihood & -22255.58 & -18630.90 & -20842.05 & -18940.80 & -16995.84 \\
\hline
\end{tabular}

Notes: The dependent variable Location equals 1 if a foreign affiliate is located in a country and 0 otherwise. Standard errors are robust to heteroskedasticity and clustered at the firm level. 
TABLE 9. Estimates of Conditional Logit Model for Non-Bank Financial Firms' Location Decisions

\begin{tabular}{|c|c|c|c|c|c|c|}
\hline Variable & (1) & (2) & (3) & (4) & (5) & (6) \\
\hline & $\begin{array}{c}\text { Full } \\
\text { Sample }\end{array}$ & $\begin{array}{c}\text { Full } \\
\text { Sample }\end{array}$ & $\begin{array}{c}\text { Firms with } \\
1-10 \\
\text { employees }\end{array}$ & $\begin{array}{c}\text { Firms with } \\
>10 \\
\text { employees }\end{array}$ & $\begin{array}{l}\text { Small } \\
\text { Firms }\end{array}$ & $\begin{array}{l}\text { Large } \\
\text { Firms }\end{array}$ \\
\hline $\operatorname{Ln}$ GDP $(+)$ & $\begin{array}{c}0.743^{* * *} \\
(0.019)\end{array}$ & $\begin{array}{c}0.720^{* * *} \\
(0.019)\end{array}$ & $\begin{array}{c}0.930^{* * *} \\
(0.039)\end{array}$ & $\begin{array}{c}0.568^{* * *} \\
(0.080)\end{array}$ & $\begin{array}{c}0.707^{* * *} \\
(0.022)\end{array}$ & $\begin{array}{c}0.837^{* * *} \\
(0.039)\end{array}$ \\
\hline Per Capita GDP (+) & $\begin{array}{c}-1.037^{* * *} \\
(0.057)\end{array}$ & $\begin{array}{c}-1.296^{* * *} \\
(0.060)\end{array}$ & $\begin{array}{c}-1.840^{* * *} \\
(0.116)\end{array}$ & $\begin{array}{c}-0.592^{*} \\
(0.275)\end{array}$ & $\begin{array}{c}-1.474^{* * *} \\
(0.068)\end{array}$ & $\begin{array}{c}-0.590^{* * *} \\
(0.136)\end{array}$ \\
\hline GDP growth (+) & $\begin{array}{c}0.122^{* * *} \\
(0.011)\end{array}$ & $\begin{array}{c}0.122^{* * *} \\
(0.011)\end{array}$ & $\begin{array}{c}0.216^{* * *} \\
(0.021)\end{array}$ & $\begin{array}{c}0.139^{* *} \\
(0.048)\end{array}$ & $\begin{array}{c}0.134^{* * *} \\
(0.013)\end{array}$ & $\begin{array}{c}0.068^{* * *} \\
(0.019)\end{array}$ \\
\hline Ln Distance (-) & $\begin{array}{c}-1.318^{* * *} \\
(0.038)\end{array}$ & $\begin{array}{c}-0.788^{* * *} \\
(0.048)\end{array}$ & $\begin{array}{c}-0.709^{* * *} \\
(0.087)\end{array}$ & $\begin{array}{c}-0.646^{* * *} \\
(0.224)\end{array}$ & $\begin{array}{c}-0.962^{* * *} \\
(0.057)\end{array}$ & $\begin{array}{c}-0.317^{* * *} \\
(0.081)\end{array}$ \\
\hline Corporation Tax (-) & $\begin{array}{c}-0.313^{* * *} \\
(0.018)\end{array}$ & $\begin{array}{c}-0.246^{* * *} \\
(0.019)\end{array}$ & $\begin{array}{c}-0.290^{* * *} \\
(0.043)\end{array}$ & $\begin{array}{l}-0.034 \\
(0.077)\end{array}$ & $\begin{array}{c}-0.229^{* * *} \\
(0.022)\end{array}$ & $\begin{array}{c}-0.196^{* * *} \\
(0.037)\end{array}$ \\
\hline Corp. Tax2 (+) & $\begin{array}{c}0.005^{* * *} \\
(0.000)\end{array}$ & $\begin{array}{c}0.004^{* * *} \\
(0.000)\end{array}$ & $\begin{array}{c}0.005^{* * *} \\
(0.001)\end{array}$ & $\begin{array}{c}0.000 \\
(0.002)\end{array}$ & $\begin{array}{c}0.004^{* * *} \\
(0.000)\end{array}$ & $\begin{array}{c}0.003^{* * *} \\
(0.001)\end{array}$ \\
\hline Unemploy. Rate $_{t-1}(?)$ & $\begin{array}{c}-0.096^{* * *} \\
(0.007)\end{array}$ & $\begin{array}{c}-0.105^{* * *} \\
(0.007)\end{array}$ & $\begin{array}{c}-0.176^{* * *} \\
(0.016)\end{array}$ & $\begin{array}{l}-0.000 \\
(0.025)\end{array}$ & $\begin{array}{c}-0.109^{* * *} \\
(0.008)\end{array}$ & $\begin{array}{c}-0.096^{* * *} \\
(0.013)\end{array}$ \\
\hline Fin. Development $t_{t-1}(+)$ & $\begin{array}{c}0.012^{* * *} \\
(0.000)\end{array}$ & $\begin{array}{c}0.013^{* * *} \\
(0.000)\end{array}$ & $\begin{array}{c}0.014^{* * *} \\
(0.001)\end{array}$ & $\begin{array}{c}0.013^{* * *} \\
(0.002)\end{array}$ & $\begin{array}{c}0.013^{* * *} \\
(0.000)\end{array}$ & $\begin{array}{c}0.013^{* * *} \\
(0.001)\end{array}$ \\
\hline OFFDIrestrict $_{t-1}(-)$ & $\begin{array}{c}-0.030^{* * *} \\
(0.004)\end{array}$ & $\begin{array}{c}-0.026^{* * *} \\
(0.004)\end{array}$ & $\begin{array}{c}-0.036^{* * *} \\
(0.010)\end{array}$ & $\begin{array}{c}0.010 \\
(0.018)\end{array}$ & $\begin{array}{l}-0.004 \\
(0.005)\end{array}$ & $\begin{array}{c}-0.096^{* * *} \\
(0.008)\end{array}$ \\
\hline Internet $(+)$ & $\begin{array}{c}0.083^{* * *} \\
(0.004)\end{array}$ & $\begin{array}{c}0.093^{* * *} \\
(0.004)\end{array}$ & $\begin{array}{c}0.113^{* * *} \\
(0.009)\end{array}$ & $\begin{array}{c}0.043^{* *} \\
(0.016)\end{array}$ & $\begin{array}{c}0.092^{* * *} \\
(0.004)\end{array}$ & $\begin{array}{c}0.075^{* * *} \\
(0.008)\end{array}$ \\
\hline Fin. Regulation (-) & $\begin{array}{c}-0.198^{* * *} \\
(0.018)\end{array}$ & $\begin{array}{c}-0.187^{* * *} \\
(0.018)\end{array}$ & $\begin{array}{c}-0.238^{* * *} \\
(0.033)\end{array}$ & $\begin{array}{l}-0.025 \\
(0.087)\end{array}$ & $\begin{array}{c}-0.108^{* * *} \\
(0.022)\end{array}$ & $\begin{array}{c}-0.409^{* * *} \\
(0.036)\end{array}$ \\
\hline Comcurr (+) & & $\begin{array}{c}0.599^{* * *} \\
(0.054)\end{array}$ & $\begin{array}{c}1.078^{* * *} \\
(0.120)\end{array}$ & $\begin{array}{c}0.401 \\
(0.254)\end{array}$ & $\begin{array}{c}0.553^{* * *} \\
(0.066)\end{array}$ & $\begin{array}{c}0.690^{* * *} \\
(0.094)\end{array}$ \\
\hline Colony (+) & & $\begin{array}{c}-0.224^{* * *} \\
(0.045)\end{array}$ & $\begin{array}{c}-0.468^{* * *} \\
(0.087)\end{array}$ & $\begin{array}{c}0.007 \\
(0.199)\end{array}$ & $\begin{array}{c}-0.268^{* * *} \\
(0.057)\end{array}$ & $\begin{array}{r}-0.098 \\
(0.075)\end{array}$ \\
\hline Common legal (+) & & $\begin{array}{c}0.445^{* * *} \\
(0.038)\end{array}$ & $\begin{array}{c}0.478^{* * *} \\
(0.072)\end{array}$ & $\begin{array}{l}0.393^{*} \\
(0.194)\end{array}$ & $\begin{array}{c}0.468^{* * *} \\
(0.045)\end{array}$ & $\begin{array}{c}0.407^{* * *} \\
(0.070)\end{array}$ \\
\hline Com language $(+)$ & & $\begin{array}{c}0.175^{* * *} \\
(0.049)\end{array}$ & $\begin{array}{c}0.129 \\
(0.097)\end{array}$ & $\begin{array}{c}0.725^{* * *} \\
(0.257)\end{array}$ & $\begin{array}{c}0.269^{* * *} \\
(0.059)\end{array}$ & $\begin{array}{c}0.061 \\
(0.091)\end{array}$ \\
\hline Contiguity (+) & & $\begin{array}{c}0.467^{* * *} \\
(0.057)\end{array}$ & $\begin{array}{c}0.687^{* * *} \\
(0.111)\end{array}$ & $\begin{array}{c}0.005 \\
(0.265)\end{array}$ & $\begin{array}{c}0.457^{* * *} \\
(0.068)\end{array}$ & $\begin{array}{c}0.440^{* * *} \\
(0.104)\end{array}$ \\
\hline$N$ & 191160 & 191160 & 58915 & 7840 & 122662 & 68498 \\
\hline Firms & 8519 & 8519 & 2621 & 382 & 5464 & 3055 \\
\hline Log-pseudolikelihood & -18630.90 & -18264.52 & -4991.97 & -846.80 & -11931.74 & -6112.80 \\
\hline
\end{tabular}

Standard errors in parentheses

${ }^{*} p<0.05,{ }^{* *} p<0.01,{ }^{* * *} p<0.001$

Notes: The dependent variable Location equals 1 if a foreign affiliate is located in a country and 0 otherwise. Standard errors are robust to heteroskedasticity and clustered at the firm level. To be classified as a large company, a company must fulfil one of the following criteria (i) annual turnover must be $€ 10$ million or more, or (ii) total assets must be $€ 20$ million or more, or (iii) the number of employees is greater than 150. Small firms refer to those who do not meet these criteria. Standard errors are robust to heteroskedasticity and clustered at the firm level. 
TABLE 10. Average Probability Elasticities (APEs) of Conditional Logit Model for Non-Bank Financial Firms' Location Decisions

\begin{tabular}{|c|c|c|c|c|c|c|}
\hline $\begin{array}{l}\text { Variable } \\
\text { (expected sion) }\end{array}$ & (1) & (2) & (3) & (4) & (5) & (6) \\
\hline & $\begin{array}{l}\text { Full } \\
\text { Sample }\end{array}$ & $\begin{array}{l}\text { Full } \\
\text { Sample }\end{array}$ & $\begin{array}{c}\text { Firms with } \\
1-10 \\
\text { employees }\end{array}$ & $\begin{array}{c}\text { Firms with } \\
>10 \\
\text { employees }\end{array}$ & $\begin{array}{l}\text { Small } \\
\text { Firms }\end{array}$ & $\begin{array}{l}\text { Large } \\
\text { Firms }\end{array}$ \\
\hline Ln GDP (+) & $\begin{array}{c}0.715^{* * *} \\
(0.019)\end{array}$ & $\begin{array}{c}0.693^{* * *} \\
(0.019)\end{array}$ & $\begin{array}{c}0.896^{* * *} \\
(0.040)\end{array}$ & $\begin{array}{c}0.547^{* * *} \\
(0.080)\end{array}$ & $\begin{array}{c}0.681^{* * *} \\
(0.022)\end{array}$ & $\begin{array}{c}0.806^{* * *} \\
(0.039)\end{array}$ \\
\hline Per Capita GDP (+) & $\begin{array}{c}-0.999^{* * *} \\
(0.057)\end{array}$ & $\begin{array}{c}-1.248^{* * *} \\
(0.060)\end{array}$ & $\begin{array}{l}-1.772^{* * *} \\
(0.116)\end{array}$ & $\begin{array}{l}-0.570^{*} \\
(0.275)\end{array}$ & $\begin{array}{c}-1.419^{* * *} \\
(0.068)\end{array}$ & $\begin{array}{l}-0.568^{* * *} \\
(0.136)\end{array}$ \\
\hline GDP growth (+) & $\begin{array}{c}0.117^{* * *} \\
(0.011)\end{array}$ & $\begin{array}{c}0.117^{* * *} \\
(0.011)\end{array}$ & $\begin{array}{c}0.208^{* * *} \\
(0.021)\end{array}$ & $\begin{array}{c}0.134^{* *} \\
(0.048)\end{array}$ & $\begin{array}{c}0.129^{* * *} \\
(0.013)\end{array}$ & $\begin{array}{c}0.066^{* * *} \\
(0.019)\end{array}$ \\
\hline Ln Distance (-) & $\begin{array}{c}-1.269^{* * *} \\
(0.038)\end{array}$ & $\begin{array}{l}-0.759^{* * *} \\
(0.048)\end{array}$ & $\begin{array}{l}-0.683^{* * *} \\
(0.087)\end{array}$ & $\begin{array}{c}-0.622 * * * \\
(0.224)\end{array}$ & $\begin{array}{c}-0.926^{* * *} \\
(0.057)\end{array}$ & $\begin{array}{c}-0.305^{* * *} \\
(0.081)\end{array}$ \\
\hline Corporation Tax (-) & $\begin{array}{c}-0.301^{* * *} \\
(0.018)\end{array}$ & $\begin{array}{c}-0.237^{* * *} \\
(0.019)\end{array}$ & $\begin{array}{c}-0.279^{* * *} \\
(0.043)\end{array}$ & $\begin{array}{l}-0.032 \\
(0.077)\end{array}$ & $\begin{array}{c}-0.221^{* * *} \\
(0.022)\end{array}$ & $\begin{array}{l}-0.189^{* * *} \\
(0.037)\end{array}$ \\
\hline Corp. Tax2 (+) & $\begin{array}{c}0.005^{* * *} \\
(0.000)\end{array}$ & $\begin{array}{c}0.004^{* * *} \\
(0.000)\end{array}$ & $\begin{array}{c}0.004^{* * *} \\
(0.001)\end{array}$ & $\begin{array}{c}0.000 \\
(0.002)\end{array}$ & $\begin{array}{c}0.003^{* * *} \\
(0.000)\end{array}$ & $\begin{array}{c}0.003^{* * *} \\
(0.001)\end{array}$ \\
\hline Unemploy. Rate Re $_{t-1}(?)$ & $\begin{array}{c}-0.093^{* * *} \\
(0.007)\end{array}$ & $\begin{array}{c}-0.101^{* * *} \\
(0.007)\end{array}$ & $\begin{array}{c}-0.169^{* * *} \\
(0.016)\end{array}$ & $\begin{array}{l}-0.000 \\
(0.025)\end{array}$ & $\begin{array}{l}-0.105^{* * *} \\
(0.008)\end{array}$ & $\begin{array}{l}-0.092^{* * *} \\
(0.013)\end{array}$ \\
\hline Fin. Development $t_{t-1}(+)$ & $\begin{array}{c}0.011^{* * *} \\
(0.000)\end{array}$ & $\begin{array}{c}0.012^{* * *} \\
(0.000)\end{array}$ & $\begin{array}{c}0.013^{* * *} \\
(0.001)\end{array}$ & $\begin{array}{l}0.012^{* * *} \\
(0.002)\end{array}$ & $\begin{array}{c}0.012^{* * *} \\
(0.000)\end{array}$ & $\begin{array}{c}0.013^{* * *} \\
(0.001)\end{array}$ \\
\hline OFFDIrestrict $_{t-1}(-)$ & $\begin{array}{c}-0.029^{* * *} \\
(0.004)\end{array}$ & $\begin{array}{l}-0.025^{* * *} \\
(0.004)\end{array}$ & $\begin{array}{c}-0.035^{* * *} \\
(0.010)\end{array}$ & $\begin{array}{c}0.009 \\
(0.018)\end{array}$ & $\begin{array}{l}-0.004 \\
(0.005)\end{array}$ & $\begin{array}{c}-0.092^{* * *} \\
(0.009)\end{array}$ \\
\hline Internet $(+)$ & $\begin{array}{c}0.080^{* * *} \\
(0.004)\end{array}$ & $\begin{array}{c}0.089^{* * *} \\
(0.004)\end{array}$ & $\begin{array}{c}0.109^{* * *} \\
(0.009)\end{array}$ & $\begin{array}{c}0.042^{* *} \\
(0.016)\end{array}$ & $\begin{array}{c}0.088^{* * *} \\
(0.004)\end{array}$ & $\begin{array}{c}0.073^{* * *} \\
(0.008)\end{array}$ \\
\hline Fin. Regulation (-) & $\begin{array}{c}-0.191^{* * *} \\
(0.018)\end{array}$ & $\begin{array}{c}-0.180^{* * *} \\
(0.018)\end{array}$ & $\begin{array}{c}-0.229^{* * *} \\
(0.033)\end{array}$ & $\begin{array}{l}-0.024 \\
(0.087)\end{array}$ & $\begin{array}{c}-0.104^{* * *} \\
(0.022)\end{array}$ & $\begin{array}{c}-0.394^{* * *} \\
(0.036)\end{array}$ \\
\hline Comcurr (+) & & $\begin{array}{c}0.577^{* * *} \\
(0.054)\end{array}$ & $\begin{array}{c}1.038^{* * *} \\
(0.120)\end{array}$ & $\begin{array}{c}0.386 \\
(0.254)\end{array}$ & $\begin{array}{c}0.533^{* * *} \\
(0.066)\end{array}$ & $\begin{array}{c}0.664^{* * *} \\
(0.094)\end{array}$ \\
\hline Colony (+) & & $\begin{array}{c}-0.216^{* * *} \\
(0.045)\end{array}$ & $\begin{array}{c}-0.451^{* * *} \\
(0.087)\end{array}$ & $\begin{array}{c}0.007 \\
(0.199)\end{array}$ & $\begin{array}{c}-0.258^{* * *} \\
(0.057)\end{array}$ & $\begin{array}{r}-0.094 \\
(0.075)\end{array}$ \\
\hline Common legal (+) & & $\begin{array}{c}0.429^{* * *} \\
(0.038)\end{array}$ & $\begin{array}{c}0.460^{* * *} \\
(0.072)\end{array}$ & $\begin{array}{l}0.378^{*} \\
(0.194)\end{array}$ & $\begin{array}{c}0.451^{* * *} \\
(0.045)\end{array}$ & $\begin{array}{c}0.392^{* * *} \\
(0.069)\end{array}$ \\
\hline Com language (+) & & $\begin{array}{c}0.169^{* * *} \\
(0.049)\end{array}$ & $\begin{array}{c}0.124 \\
(0.097)\end{array}$ & $\begin{array}{c}0.698^{* * *} \\
(0.257)\end{array}$ & $\begin{array}{c}0.208^{* * *} \\
(0.059)\end{array}$ & $\begin{array}{c}0.059 \\
(0.091)\end{array}$ \\
\hline Contiguity (+) & & $\begin{array}{c}0.450^{* * *} \\
(0.057)\end{array}$ & $\begin{array}{c}0.662^{* * *} \\
(0.111)\end{array}$ & $\begin{array}{c}0.005 \\
(0.265)\end{array}$ & $\begin{array}{c}0.440^{* * *} \\
(0.068)\end{array}$ & $\begin{array}{c}0.424^{* * *} \\
(0.104)\end{array}$ \\
\hline$N$ & 191160 & 191160 & 58915 & 7840 & 122662 & 68498 \\
\hline Firms & 8519 & 8519 & 2621 & 352 & 5464 & 3055 \\
\hline Log-pseudolikelihood & -18630.90 & -18264.52 & -4991.97 & -846.80 & -11931.74 & -6112.80 \\
\hline
\end{tabular}

Notes: Figures shown are average probability elasticities (APEs) as described in Head and Mayer (2004). The APEs in the conditional logit model are calculated as follows: $e_{x}=\beta_{x}(1-(1 \div J))$ where $\beta_{x}$ is the estimated parameter for $\mathrm{x}$ reported in Table 10 and $\mathrm{J}$ is the number of alternative countries in the choice set. The dependent variable Location equals 1 if a foreign affiliate is located in a country and 0 otherwise. Standard errors are robust to heteroskedasticity and clustered at the firm level. To be classified as a large company, a company must fulfil one of the following criteria (i) annual turnover must be $€ 10$ million or more, or (ii) total assets must be $€ 20$ million or more, or (iii) the number of employees is greater than 150. Small firms refer to those who do not meet these criteria. 


\section{TABLE 11. Estimates of Conditional Logit Model for Non-Bank Financial Firms' Location Decisions on Sub-Samples (Robustness Checks)}

\begin{tabular}{|c|c|c|c|c|c|c|c|}
\hline Variable & (1) & (2) & (3) & (4) & (5) & (6) & (7) \\
\hline & $\begin{array}{c}\text { Home } \\
\text { Country } \\
\text { (OECD only) }\end{array}$ & $\begin{array}{c}\text { Home } \\
\text { Country } \\
\text { (OECD excl. } \\
\text { CH, IE, } \\
\text { LU \& NL) }\end{array}$ & $\begin{array}{c}\text { Home } \\
\text { Country } \\
\text { (excl. US) }\end{array}$ & $\begin{array}{c}\text { Home } \\
\text { Country } \\
\text { (EU28 only) }\end{array}$ & $\begin{array}{c}\text { All NACE } \\
\text { sectors (excl. } \\
\text { fin. } \\
\text { holding } \\
\text { companies) }\end{array}$ & $\begin{array}{c}\text { Home } \\
\text { Country (excl. } \\
\text { offshore fin. } \\
\text { centres) }\end{array}$ & $\begin{array}{l}\text { Home } \\
\text { Country } \\
\text { (excl. } \\
\text { tax } \\
\text { havens) }\end{array}$ \\
\hline $\operatorname{Ln}$ GDP (+) & $\begin{array}{c}0.770^{* * *} \\
(0.022)\end{array}$ & $\begin{array}{c}0.740^{* * *} \\
(0.025)\end{array}$ & $\begin{array}{c}0.684^{* * *} \\
(0.020)\end{array}$ & $\begin{array}{c}0.693^{* * *} \\
(0.024)\end{array}$ & $\begin{array}{c}0.739 * * * \\
(0.033)\end{array}$ & $\begin{array}{c}0.720^{* * *} \\
(0.020)\end{array}$ & $\begin{array}{c}0.707^{* * *} \\
(0.021)\end{array}$ \\
\hline Per Capita GDP (+) & $\begin{array}{c}-1.131^{* * *} \\
(0.072)\end{array}$ & $\begin{array}{c}-1.256^{* * *} \\
(0.082)\end{array}$ & $\begin{array}{c}-1.266^{* * *} \\
(0.064)\end{array}$ & $\begin{array}{c}-1.201^{* * *} \\
(0.080)\end{array}$ & $\begin{array}{l}-0.059 \\
(0.097)\end{array}$ & $\begin{array}{c}-1.235^{* * *} \\
(0.063)\end{array}$ & $\begin{array}{c}-1.321^{* * *} \\
(0.108)\end{array}$ \\
\hline GDP growth $(+)$ & $\begin{array}{c}0.105^{* * *} \\
(0.012)\end{array}$ & $\begin{array}{c}0.108^{* * *} \\
(0.014)\end{array}$ & $\begin{array}{c}0.117^{* * *} \\
(0.011)\end{array}$ & $\begin{array}{c}0.102^{* * *} \\
(0.013)\end{array}$ & $\begin{array}{c}0.113^{* * *} \\
(0.015)\end{array}$ & $\begin{array}{c}0.117^{* * *} \\
(0.011)\end{array}$ & $\begin{array}{c}0.125^{* * *} \\
(0.012)\end{array}$ \\
\hline Ln Distance (-) & $\begin{array}{c}-0.857^{* * *} \\
(0.055)\end{array}$ & $\begin{array}{c}-0.770^{* * *} \\
(0.075)\end{array}$ & $\begin{array}{c}-0.875^{* * *} \\
(0.047)\end{array}$ & $\begin{array}{c}-1.063^{* * *} \\
(0.050)\end{array}$ & $\begin{array}{c}-1.035^{* * *} \\
(0.079)\end{array}$ & $\begin{array}{c}-0.800^{* * *} \\
(0.050)\end{array}$ & $\begin{array}{c}-0.726^{* * *} \\
(0.061)\end{array}$ \\
\hline Corporation Tax (-) & $\begin{array}{c}-0.183^{* * *} \\
(0.021)\end{array}$ & $\begin{array}{c}-0.189^{* * *} \\
(0.025)\end{array}$ & $\begin{array}{c}-0.206^{* * *} \\
(0.020)\end{array}$ & $\begin{array}{c}-0.122 * * * \\
(0.024)\end{array}$ & $\begin{array}{c}-0.345^{* * *} \\
(0.025)\end{array}$ & $\begin{array}{c}-0.232^{* * *} \\
(0.020)\end{array}$ & $\begin{array}{c}-0.247^{* * *} \\
(0.021)\end{array}$ \\
\hline Corp. Tax2 (+) & $\begin{array}{c}0.003^{* * *} \\
(0.000)\end{array}$ & $\begin{array}{c}0.003^{* * *} \\
(0.000)\end{array}$ & $\begin{array}{c}0.003^{* * *} \\
(0.000)\end{array}$ & $\begin{array}{c}0.001^{* *} \\
(0.000)\end{array}$ & $\begin{array}{c}0.005^{* * *} \\
(0.000)\end{array}$ & $\begin{array}{c}0.004^{* * *} \\
(0.000)\end{array}$ & $\begin{array}{c}0.004^{* * *} \\
(0.001)\end{array}$ \\
\hline Unemploy. Rate R $_{t-1}(?)$ & $\begin{array}{c}-0.091^{* * *} \\
(0.008)\end{array}$ & $\begin{array}{c}-0.102 * * * \\
(0.009)\end{array}$ & $\begin{array}{c}-0.090^{* * *} \\
(0.007)\end{array}$ & $\begin{array}{c}-0.066^{* * *} \\
(0.008)\end{array}$ & $\begin{array}{c}0.031^{* * *} \\
(0.009)\end{array}$ & $\begin{array}{c}-0.095^{* * *} \\
(0.007)\end{array}$ & $\begin{array}{c}-0.102^{* * *} \\
(0.008)\end{array}$ \\
\hline Fin. Development $t_{t-1}(+)$ & $\begin{array}{c}0.012^{* * *} \\
(0.000)\end{array}$ & $\begin{array}{c}0.012^{* * *} \\
(0.001)\end{array}$ & $\begin{array}{c}0.012^{* * *} \\
(0.000)\end{array}$ & $\begin{array}{c}0.010^{* * *} \\
(0.001)\end{array}$ & $\begin{array}{c}0.005^{* * *} \\
(0.001)\end{array}$ & $\begin{array}{c}0.012^{* * *} \\
(0.000)\end{array}$ & $\begin{array}{c}0.012^{* * *} \\
(0.000)\end{array}$ \\
\hline OFFDIrestrict $_{t-1}(-)$ & $\begin{array}{c}-0.034^{* * *} \\
(0.005)\end{array}$ & $\begin{array}{c}-0.026^{* * *} \\
(0.006)\end{array}$ & $\begin{array}{c}-0.015^{* *} \\
(0.005)\end{array}$ & $\begin{array}{l}-0.010 \\
(0.006)\end{array}$ & $\begin{array}{c}0.048^{* * *} \\
(0.005)\end{array}$ & $\begin{array}{c}-0.024^{* * *} \\
(0.005)\end{array}$ & $\begin{array}{c}-0.015^{* * *} \\
(0.005)\end{array}$ \\
\hline Internet $(+)$ & $\begin{array}{c}0.082^{* * *} \\
(0.004)\end{array}$ & $\begin{array}{c}0.090 * * * \\
(0.005)\end{array}$ & $\begin{array}{c}0.089^{* * *} \\
(0.004)\end{array}$ & $\begin{array}{c}0.075^{* * *} \\
(0.005)\end{array}$ & $\begin{array}{c}0.040^{* * *} \\
(0.005)\end{array}$ & $\begin{array}{c}0.092^{* * *} \\
(0.004)\end{array}$ & $\begin{array}{c}0.099 * * * \\
(0.005)\end{array}$ \\
\hline Fin. Regulation (-) & $\begin{array}{c}-0.169^{* * *} \\
(0.022)\end{array}$ & $\begin{array}{c}-0.234^{* * *} \\
(0.024)\end{array}$ & $\begin{array}{c}-0.103^{* * *} \\
(0.019)\end{array}$ & $\begin{array}{c}-0.058^{*} \\
(0.023)\end{array}$ & $\begin{array}{c}0.115^{* * *} \\
(0.029)\end{array}$ & $\begin{array}{c}-0.168^{* * *} \\
(0.020)\end{array}$ & $\begin{array}{c}-0.195^{* * *} \\
(0.021)\end{array}$ \\
\hline Comcurr (+) & $\begin{array}{c}0.586^{* * *} \\
(0.055)\end{array}$ & $\begin{array}{c}0.224^{* *} \\
(0.070)\end{array}$ & $\begin{array}{c}0.687^{* * *} \\
(0.053)\end{array}$ & $\begin{array}{c}0.815^{* * *} \\
(0.056)\end{array}$ & $\begin{array}{l}-0.036 \\
(0.085)\end{array}$ & $\begin{array}{c}0.589 * * * \\
(0.054)\end{array}$ & $\begin{array}{c}0.423^{* * *} \\
(0.061)\end{array}$ \\
\hline Colony (+) & $\begin{array}{c}-0.305^{* * *} \\
(0.049)\end{array}$ & $\begin{array}{c}-0.759^{* * *} \\
(0.079)\end{array}$ & $\begin{array}{l}-0.079 \\
(0.053)\end{array}$ & $\begin{array}{l}-0.115 \\
(0.064)\end{array}$ & $\begin{array}{c}0.189 * * \\
(0.069)\end{array}$ & $\begin{array}{c}-0.190 * * * \\
(0.045)\end{array}$ & $\begin{array}{c}-0.361^{* * *} \\
(0.065)\end{array}$ \\
\hline Common legal (+) & $\begin{array}{c}0.499^{* * *} \\
(0.045)\end{array}$ & $\begin{array}{c}0.415^{* * *} \\
(0.060)\end{array}$ & $\begin{array}{c}0.456^{* * *} \\
(0.038)\end{array}$ & $\begin{array}{c}0.424^{* * *} \\
(0.048)\end{array}$ & $\begin{array}{c}0.445^{* * *} \\
(0.061)\end{array}$ & $\begin{array}{c}0.497^{* * *} \\
(0.040)\end{array}$ & $\begin{array}{c}0.376^{* * *} \\
(0.048)\end{array}$ \\
\hline Com language $(+)$ & $\begin{array}{c}0.094 \\
(0.057)\end{array}$ & $\begin{array}{c}0.564^{* * *} \\
(0.081)\end{array}$ & $\begin{array}{c}0.338^{* * *} \\
(0.054)\end{array}$ & $\begin{array}{c}0.274^{* * *} \\
(0.070)\end{array}$ & $\begin{array}{c}0.629^{* * *} \\
(0.080)\end{array}$ & $\begin{array}{l}0.0516 \\
(0.053)\end{array}$ & $\begin{array}{c}0.286^{* * *} \\
(0.072)\end{array}$ \\
\hline Contiguity (+) & $\begin{array}{c}0.385^{* * *} \\
(0.062)\end{array}$ & $\begin{array}{c}0.577^{* * *} \\
(0.076)\end{array}$ & $\begin{array}{c}0.252^{* * * *} \\
(0.059)\end{array}$ & $\begin{array}{c}0.069 \\
(0.065)\end{array}$ & $\begin{array}{l}-0.053 \\
(0.092)\end{array}$ & $\begin{array}{c}0.485^{* * *} \\
(0.059)\end{array}$ & $\begin{array}{c}0.641^{* * *} \\
(0.068)\end{array}$ \\
\hline$N$ & 152601 & 115860 & 149051 & 98414 & 59219 & 172067 & 145718 \\
\hline Firms & 6837 & 5177 & 6680 & 4473 & 2649 & 7686 & 6495 \\
\hline Log-pseudolikelihood & -14485.90 & -10957.21 & -14574.43 & -9710.09 & -6157.95 & -16500.04 & -14028.71 \\
\hline
\end{tabular}

Standard errors in parentheses

${ }^{*} p<0.05,{ }^{* *} p<0.01,{ }^{* * *} p<0.001$

Notes: The dependent variable Location equals 1 if a foreign affiliate is located in a country and 0 otherwise. Standard errors are robust to heteroskedasticity and clustered at the firm level. 